\section{Marine Geology}

Vol. 241, Issues 1-4, 25 June 2007, Pages 93-109

http://dx.doi.org/10.1016/j.margeo.2007.03.007

(c) 2007 Elsevier B.V. All rights reserved
Archimer, archive institutionnelle de l'Ifremer http://www.ifremer.fr/docelec/

\title{
Sr/Ca and Mg/Ca ratios in Niger Delta sediments: Implications for authigenic carbonate genesis in cold seep environments
}

\author{
G. Bayon ${ }^{a,{ }^{*}}$, C. Pierre ${ }^{b}$, J. Etoubleau ${ }^{a}$, M. Voisset $^{a}$, E. Cauquil ${ }^{c}$, T. Marsset $^{a}$, \\ N. Sultan ${ }^{a}$, E. Le Drezen ${ }^{a}$ and Y. Fouquet ${ }^{a}$ \\ a IFREMER, Département Géosciences Marines, Brest, France \\ ${ }^{\mathrm{b}}$ LOCEAN, Université Pierre et Marie Curie, Paris, France \\ ${ }^{\mathrm{c}}$ TOTAL, Paris, France \\ *: Corresponding author : gbayon@ifremer.fr
}

\begin{abstract}
:
We report on a reconnaissance analysis of the geochemical composition of authigenic carbonates and sediment samples collected from various seepage sites on the Niger deep-sea fan. Our aim has been to investigate whether evidence for the presence of authigenic carbonates and gas hydrates within sediments is discernible from solid-phase sediment geochemistry. We show that sedimentary $\mathrm{Sr} / \mathrm{Ca}$ and $\mathrm{Mg} / \mathrm{Ca}$ ratios can be used to infer the presence of authigenic aragonite (Sr-rich) and Mg-rich carbonate phases (high-Mg calcite, dolomite) in cold seep settings. Using $\mathrm{Sr} / \mathrm{Ca}$ and $\mathrm{Mg} / \mathrm{Ca}$ ratios, the proportion (wt.\%) of authigenic carbonates in Niger Fan sediments can be calculated from a mixing model between sediment fractions of terrigenous material, biogenic calcite, aragonite and high-Mg calcite. This approach was applied to high-resolution geochemical profiles along sediment cores recovered from various cold seep settings (mud volcano, diapirs, pockmarks, gas-hydrate bearing sediments). Our data reveal that authigenic carbonates occur as discrete phases in sediments from gas-hydrate-bearing areas, suggesting that such carbonate-rich sediment layers may represent paleoindicators for ancient methane seepage in marine sediments, possibly associated to gas-hydrate reservoirs.
\end{abstract}

Keywords: authigenic carbonates; Sr/Ca; Mg/Ca; cold seeps; gas hydrates; Niger Delta 


\section{Introduction}

Since their first discovery in 1984, on the Cascadia margin (Suess et al., 1985; Kulm et al., 1986; Ritger et al., 1987), numerous deposits of carbonate crusts and nodules have been documented on continental margins, in areas where gas-rich fluids escape from the seafloor (e.g. Ritger et al., 1987; Matsumoto, 1989, 1990; Hovland et al., 1997; Bohrmann et al., 1998; Aloisi et al., 2000; Pierre et al., 2000; Greinert et al., 2001; Mazzini et al., 2004; Orphan et al., 2004). It is now well established that carbonate precipitation in cold seep environments is closely related to the anaerobic oxidation of methane (AOM). Methane is oxidised when gas-rich fluids migrating upward, toward the seafloor, encounter seawater sulfate. The AOM is driven by a consortium of microbes (e.g. Boetius et al., 2000), which releases bicarbonate $\left(\mathrm{HCO}_{3}{ }^{-}\right)$and sulfide (HS) into surrounding pore waters. In such cold seep settings, a significant portion of $\mathrm{HCO}_{3}{ }^{-}$ produced through AOM precipitates as authigenic carbonates (Luff and Wallman, 2003).

Two main types of cold seep carbonates have been described previously; chemoherm carbonates and carbonate cemented mudstones, which relate to distinct formation processes in cold seep environments (see Greinert et al., 2001). Chemoherm complexes correspond to those massive deposits, composed of various fragments of shells cemented by authigenic carbonates (typically aragonite), which develop on the seafloor above focussed fluid flow pathways (e.g. faults). Carbonate mudstones may precipitate instead at various depths within the sediment column, whenever carbonate supersaturation is induced by diagenetic processes. Mudstones exhibit a wide variety of lithologies (e.g., crusts, nodules, small concretions) and carbonate compositions (e.g., aragonite, high-Mg calcite, dolomite, siderite), depending on their mode of formation.

Authigenic carbonates may also be present as dispersed discrete phases within cold seep sediments (e.g., Rodriguez et al., 2000; Pierre et al., 2000). For example, a mineralogical study of gas-hydrate-bearing sediments from the Blake Ridge (ODP Leg 164; off southeastern North America) showed clearly that such discrete carbonate phases could occur throughout the sedimentary column, in relation with the presence of gas 
hydrates (Naehr et al., 2000; Pierre et al., 2000; Rodriguez et al., 2000). Identification of such carbonate phases in marine sediment records can hence provide a window into the distribution and magnitude of ancient seep settings. The advent of XRF core scanners (Jansen et al., 1998; Koshikawa et al., 2003), which allow rapid determination of subcontinuous geochemical profiles along sediment cores, could provide in future studies a new tool for identifying methane-derived carbonate-rich layers in marine sediments. But first, the assumption that elemental signatures may represent reliable indicators of methane-derived carbonates in marine sediments needs to be validated.

The main purpose of this study has been to analyse bulk sediments collected from various cold seep environments on the Niger deep-sea fan to investigate whether geochemical signatures of authigenic carbonates can be detected. Sediments, nodules of gas hydrates and authigenic carbonates were collected by sediment coring and dredging during two expeditions on the continental slope off Nigeria (NERIS $1 \&$ 2; PI's: M. Voisset and E. Cauquil), in 2003 and 2004. The work presented here focuses primarily on the inorganic geochemical composition of authigenic carbonates and sediment solid phases. We show that $\mathrm{Sr} / \mathrm{Ca}$ and $\mathrm{Mg} / \mathrm{Ca}$ ratios can be used as proxies for the presence of discrete authigenic carbonate phases (aragonite and high-Mg carbonates) in cold seep sediments.

\section{Geological setting and samples}

The area investigated during the NERIS project is located in the deep province of the Niger Delta (Gulf of Guinea, West African margin), between $1100 \mathrm{~m}$ and $1700 \mathrm{~m}$ water depths (Fig. 1). In this area, compressional gravity tectonism has deformed sediments over the continental slope, leading to folding, diapirism and faulting, all of which have created intraslope basins that are now filled with thick sedimentary sequences (Burke, 1972; Cohen and McClay, 1996). Occurrence of mud diapirs and other fluid escape structures have been reported previously on the Niger Delta deep province (Mascle et al., 1973; Brooks et al., 1994; Cohen and McClay, 1996). 
Authigenic carbonates and sediments used for this study were collected from three distinct areas (Fig. 2): the Mud Volcano area, the Diapir area and the Pockmark area. The lengths and water depths of the cores investigated are specified in Table 1 and their positions are displayed in Figure 2. Coring sites were selected based on bathymetric and geophysical data acquired during the NERIS cruises (EM300 multibeam bathymetry, 3,5 $\mathrm{kHz}$ profiles, CHIRP seismic data and SAR/PASISAR deep-tow sonar imagery; Marsset et al., 2005). With the exception of carbonate sample N2-DR-51, recovered by dredging, all authigenic carbonates reported in this study were collected from within Kullenberg piston cores and interface sediment cores. Two reference cores (N1-KI-04, N2-KI-13) were collected in areas away from any fluid escape structures.

The Mud Volcano area corresponds to a giant volcano (diameter $\sim 4 \mathrm{~km}$; height $\sim 170$ m), associated with numerous pockmarks. Cores N1-KSF-12 and N1-KS-13 were raised from close to the volcano summit in a recent mudflow (Marsset et al., 2005), from which several clasts and carbonate mudstones were collected.

The Diapir area is characterized by the presence of topographic mounds on the seafloor (diameter 650-800 m), which have been interpreted, in absence of any discernible mud flows on the seafloor, as shale extrusions. Those extrusions are encountered within a field of pockmarks related to buried paleo turbiditic channels (Marsset et al., 2005). Cores N1-KSF-45 and N1-KI-47 were recovered from one of these shale extrusions, which exhibit oil traces and carbonate mudstones. Core N1-KSF07 and dredge N2-DR-51 were raised from the southern part of the Diapir area (Fig. 2), in an area exhibiting highly-reflective patches on acoustic imagery data. Carbonates collected at this site correspond to massive carbonate chemoherms.

The Pockmark area is a complex zone of $c a .20 \mathrm{~km}^{2}$, delimited by two deep-rooted normal faults oriented $\mathrm{N} 130^{\circ}$. This area corresponds to the collapsed summit of an anticline and is characterised by the presence of numerous pockmarks on the seafloor. Many fluid escape structures (e.g., pockmarks, massive carbonate pavements) occur in close proximity to the two major faults, indicating that those deep-rooted fractures act as preferential conduits to fluid flow toward the seafloor. Cores N1-KS-22 and N1-KSF-28, 
collected from close to the northern major fault (subsequently referred as to the northern fault zone; Fig. 2), contain many chemoherm carbonates and associated bivalves. In the southern part of the Pockmark area (i.e. the southern pockmark zone; Fig. 2), some pockmarks are related to the presence of buried paleo-turbiditic channels (Huguen, 2003). Many pockmarks of variable diameter (from $\sim 10 \mathrm{~m}$ to $400 \mathrm{~m}$ ) are also present in the central part of the Pockmark area (i.e. the hydrate zone; Fig. 2), many of which are in close association with gas hydrates. Gas hydrates and numerous authigenic carbonates (mainly carbonate-cemented breccias) were retrieved in most sediment cores from this area (Table 2).

In this study, we have focused more specifically on one sediment core (N2-KS-44) raised from the hydrate zone. Core N2-KS-44 had a total length of $7 \mathrm{~m}$, but contained massive nodules of gas hydrates at sediment depths below $\sim 4 \mathrm{~m}$. Therefore, only sediments from the top $3.6 \mathrm{~m}$ part of that core were recovered successfully. Sediments in core N2-KS-44 and all other cores recovered from the Pockmark and Diapir areas consist of dark grey-brown foraminiferal ooze. No evidence for turbidite or slump deposition was observed in core N2-KS-44 or in any of the other studied cores. A few concretions (mm- to cm-size) of authigenic carbonates were observed along core N2-KS-44, between 30 and $260 \mathrm{~cm}$ sediment depths.

\section{Methods}

\subsection{Petrography, mineralogy and electron microprobe analysis of authigenic carbonates}

Authigenic carbonate samples were studied and described on hand specimens, slabs and polished thin sections using light and scanning electron microscopy (JEOL JSM840A, University of Oxford). Electron microprobe analyses were carried out with a JEOL JXA-8800R at Oxford University. Analyses were generally obtained using an accelerating voltage of $15 \mathrm{kV}$ and a beam current of $10 \mathrm{nA}$. The bulk mineralogical composition of authigenic carbonate and sediment samples was determined by X-ray 
diffraction. The abundance of different carbonate minerals in sediments was determined using prepared calibration curves and by adding an internal standard (corundum) to each sample.

Most mudstones recovered from cores N1-KSF-12 and N1-KS-13 correspond to siderite-rich concretions (Table 2; Fig. 3). Carbonate-cemented mudstones recovered in the Diapir area correspond to homogeneous nodules of dolomite (Fig. 3). In the southern area of the Diapir area, chemoherm carbonates correspond to intraformational breccias, similar to those described by Greinert et al. (2001). They contain decimeter-size clasts of bivalves (Vesicomyidae, Mytilidae), cemented by white botryoidal aragonite and, to a lesser extent, high-Mg calcite (Fig. 3).

In the Pockmark area, most carbonate concretions correspond to carbonate-cemented breccias (Table 2; Fig. 3). Two types of mudclasts were differentiated: a porous and light type, cemented by sparite aragonite, and a dense, darker type, which contains both aragonite and high-Mg calcite. The size of those concretions ranges from a few millimeters to a few centimeters. Porous mudclasts exhibit large (up to $\sim 100 \mu \mathrm{m}$ diameter) crystals of fibrous aragonite, which have developed in open pore space, either between intraclasts or inside the cavities of biogenic components (e.g. foraminifers, bivalve shells). In dense mudclasts, the intraclasts consist primarily of mudstones cemented by micritic high-Mg calcite, which exhibit a darker color than the surrounding matrix and contain framboidal pyrite. Similar petrographic features were described previously in Hydrate Ridge authigenic carbonates (Naehr et al., 2000; Greinert et al., 2001), which were attributed to carbonates forming within near-surface gas hydrate deposits.

\subsection{Major element geochemistry}

The inorganic geochemical composition of 21 authigenic carbonates was determined by wavelength-dispersive X-ray fluorescence (WD-XRF) analysis of fusion beads or compressed powder pellets for major and minor elements, respectively. For sediment analysis, our aim was to perform high-resolution $(\sim 1-5 \mathrm{~cm})$ geochemical profiles along selected sediment cores. Such a high-resolution approach is incompatible however with 
conventional XRF analyses, which are time consuming and cause significant loss of sediment. Therefore, we have modified our analytical procedure to allow the analysis of small amounts $(\sim 200 \mathrm{mg})$ of sediment samples. Although this approach affects the accuracy of data, it enables to achieve high resolution geochemical records along sediment cores and to perform a large number of XRF measurements, rapidly. The sampling reproducibility was assessed by analysing a suite of subsamples from two distinct $1 \mathrm{~cm}$ thick sediment layers: a sediment horizon $\left(\mathrm{N} 2-\mathrm{KS}-44 \_78 \mathrm{~cm}\right)$ containing numerous mm-size carbonate cemented breccias and a carbonate-poor layer (N2-KS44_218 cm). Those carbonate-rich and carbonate-poor sediment layers yielded e.g. calcium concentrations $(\mathrm{CaO} w t \%)$ of $19.5 \pm 1.9 \%(\mathrm{n}=8)$ and $3.9 \pm 0.4 \%(\mathrm{n}=8)$, respectively.

The preparation of the samples is straightforward and rapid. About $200 \mathrm{mg}$ of dried sediment were crushed into powder in a ceramic mortar and compressed by hand, without any ligand, as mini-pellets (diameter: $8 \mathrm{~mm}$ ) before XRF analysis. Major elements (Fe, $\mathrm{Mn}, \mathrm{Ti}, \mathrm{Ca}, \mathrm{K}, \mathrm{P}, \mathrm{Si}, \mathrm{Al}, \mathrm{Mg})$ and minor elements (Ba, Sr) were determined during each analytical run. After data acquisition, measured net peak intensities corrected from inter element effects were converted into concentrations using calibration curves generated from the analysis of certified geochemical standard powders, measured under identical analytical conditions. The accuracy of our modified analytical procedure was assessed by comparing mini-pellet data with conventional XRF data for a large number of sediment samples, during the whole run period (from 02/2003 to 10/2004), including 30 sediments from the Niger Delta deep province. Comparison between mini-pellet data and conventional data showed that our modified analytical procedure could provide robust semi-quantitative information for Fe, Mn, Ti, K, P, Si and Al. The correlations between mini-pellet and conventional data are most satisfactory for $\mathrm{Ca}, \mathrm{Sr}, \mathrm{Ba}$ and $\mathrm{Mg}$, indicating that quantitative information for those elements can be obtained from mini-pellet data. An illustration of these correlations for Niger Delta sediments is given in Fig. 4. The regression analyses show strong positive correlations for $\mathrm{Ca}, \mathrm{Sr}$ and $\mathrm{Mg}$, which can be used to convert mini-pellet data into quantitative concentrations. Those regression analyses indicate that the 2 see errors (standard error of the estimate; see Fig. 4) on $\mathrm{Ca}, \mathrm{Sr}$ 
and $\mathrm{Mg}$ concentrations predicted from mini-pellet analyses are $0.69 \%, 18 \mathrm{ppm}$ and $0.4 \%$, respectively.

\subsection{Stable isotope analysis}

Stable isotope ratios were determined on a suite of 58 sediment and 2 authigenic carbonate samples from core N2-KS-44 (Pockmark area, hydrate zone). Stable isotope compositions were measured on bulk carbonate fractions of sediments collected every 5 $\mathrm{cm}$ along the entire length of the core, on those same powders analysed by X-ray fluorescence. The $\mathrm{CO}_{2}$ released after 20 min of reaction at $25^{\circ} \mathrm{C}$ with $100 \%$ phosphoric acid was considered to come solely from calcite and/or aragonite The $\mathrm{CO}_{2}$ gas was analysed using a Finnigan Delta E triple collector mass spectrometer. The isotopic compositions are expressed using the conventional $\delta$ notation relative to the Peedee belemnite (PDB) reference. The analytical precision is $0.1 \%$ for both $\delta^{18} \mathrm{O}$ and $\delta^{13} \mathrm{C}$ values.

\section{Results}

\subsection{Major element composition of authigenic carbonates}

$\mathrm{XRF}$ major element concentrations and representative electron microprobe analyses of authigenic carbonates are listed in Table 3 and Table 4, respectively. Various carbonate minerals of different size have been analysed by electron microprobe analyzer: fibrous crystals of aragonite $(\sim 20-100 \mu \mathrm{m})$, botryoidal aragonite $(\sim 2-10 \mu \mathrm{m})$, microcrystalline aragonite and high-Mg calcite cements $(<2 \mu \mathrm{m})$, and bioclasts (bivalves, foraminifers). Calcium $(\mathrm{CaO})$ concentrations vary from $\sim 2$ wt $\%$ in siderite nodules to $48 \%$ in aragonite concretions. Sr contents are much higher in aragonite concretions (from $\sim 5000$ to $7000 \mathrm{ppm}$ ) than in any other authigenic carbonates (from 100 to $1000 \mathrm{ppm}$ ). Fibrous aragonite exhibits Sr concentrations up to 1.2\% (12000 ppm; Table 4), higher than in botryoidal aragonite and aragonite cement (mean average $\sim 0.82 \%$ ). Mg concentrations 
are high in siderite (from $\mathrm{MgO} \sim 7$ to $16 \mathrm{wt} \%$ ), dolomite $(\sim 8-13 \%)$ and high-Mg calcite nodules (from $\sim 4$ to $14 \%$ ), and low in aragonite concretions and minerals (from $\sim 0.01$ to $4 \%$ ). Bulk carbonate concretions exhibit high contents of detrital elements (e.g. Al, $\mathrm{Si}, \mathrm{K}$ ), indicating that terrigenous clay-rich material is incorporated within the carbonate matrix during the formation of authigenic carbonate concretions.

\subsection{Major element composition of sediments}

Major element concentrations of sediments analysed by conventional X-ray fluorescence are listed in Table 5. In addition, down-core high-resolution profiles of $\mathrm{CaO}$ (wt \%), $\mathrm{Sr}(\mathrm{ppm}), \mathrm{MgO}$ (wt \%), $\mathrm{Sr} / \mathrm{Ca}$ and $\mathrm{Mg} / \mathrm{Ca}$ (wt ratio), calibrated from mini-pellet analyses (see Methods), are given in Fig. 5. The low carbonate contents in reference sediments collected away from fluid-venting areas reflect the dominance of terrigenous material on the Niger Delta deep province (Fig 5b). Sr and $\mathrm{MgO}$ concentrations in reference sediments range approximately between 200-500 ppm and 1-2 \%, respectively. Variations in elemental concentrations along Niger Fan reference cores are induced by a dilution effect between biogenic carbonates and terrigenous material, related to Late Quaternary climate changes (e.g., Zabel et al., 2001). Other sediment cores from the Diapir (N1-KI-47; Fig. 5a) and Pockmark areas (N2-KI-20, N2-KI-28; Fig. 5b) display geochemical characteristics similar to the reference cores. In contrast, sediments associated with mudflows from the Mud Volcano area (core N1-KSF-12; Fig. 5c) exhibit higher concentrations in $\mathrm{SiO}_{2}(\sim 50 \%)$ and $\mathrm{MgO}$ (from $\sim 3$ to $8 \%$ ), and lower $\mathrm{CaO}(\sim$ $1 \%)$ and $\mathrm{Sr}(\sim 100 \mathrm{ppm})$ contents. In the hydrate zone (Pockmark area), sediments (cores N1-KI-27 and N2-KS-44) display CaO (from 10 to $25 \%$; Fig. 5b), $\mathrm{Sr}$ (from 500 to $3000 \mathrm{ppm}$ ) and $\mathrm{MgO}$ (from 2 to $4 \%$ ) concentrations much higher than in reference sediments. Major element concentrations vary drastically along those two cores (e.g. $\mathrm{CaO}$ contents vary from less than $1 \%$ to $\sim 25 \%$; Fig. $5 \mathrm{c}$ ).

\subsection{Oxygen and carbon isotopes}


Down-core $\delta^{18} \mathrm{O}$ and $\delta^{13} \mathrm{C}$ profiles for bulk carbonate fractions from core N2-KS-44 sediments (hydrate zone) are displayed in Fig. 6. Carbon isotopic compositions exhibit drastic changes throughout the whole core, from $\delta^{13} \mathrm{C} \sim 0$ to $\sim 29 \%$. The range of $\delta^{18} \mathrm{O}$ values for bulk carbonate fractions vary within the range $\sim+1-+5 \%$ o between 0 to 280 $\mathrm{cm}$ depth, then exhibit a trend towards higher values (+9\%; Fig. 6) below $280 \mathrm{~cm}$. The two authigenic carbonate concretions exhibit $\delta^{18} \mathrm{O}$ and $\delta^{13} \mathrm{C}$ values of $\sim+5 \%$ and $\sim-37$ $\%$, respectively.

\section{Discussion}

\subsection{Quantifying authigenic carbonate contents in sediments using $\mathrm{Sr} / \mathrm{Ca}$ and $\mathrm{Mg} / \mathrm{Ca}$ ratios}

$\mathrm{Sr} / \mathrm{Ca}$ and $\mathrm{Mg} / \mathrm{Ca}$ values for authigenic carbonates (bulk concretions and individual mineral phases) from the Niger Delta deep province are plotted in Fig. 7. Bulk aragonite concretions analysed in this study display $\mathrm{Sr} / \mathrm{Ca}$ ratios between 0.015 to 0.028 , very similar to those measured by electron microprobe in individual aragonite minerals $(0.016-$ 0.034, Table 4; Naehr et al., 2000). Cold seep carbonate concretions are often composed by a mixture of different components (e.g. aragonite, high-Mg calcite, calcite, detrital material), rather than being monomineral phases. This is shown nicely when comparing $\mathrm{Sr} / \mathrm{Ca}$ (wt ratio) and $\mathrm{Si}$ (wt \%) for all carbonates analysed by electron-microprobe (Table 4). Large fibrous crystals of aragonite, developed in open pore spaces and cavities, contain much less detrital material ( $<2 \mathrm{wt} \%$ Si contents) than botryoidal aragonite $(<2.5$ $\% \mathrm{Si}$ ), and microcrystalline aragonite $(<5 \% \mathrm{Si})$ and high- $\mathrm{Mg}$ calcite (up to $7 \% \mathrm{Si}$ ) cements. This shows that carbonate minerals can incorporate detrital material (i.e. clays) during carbonate precipitation. In Fig. 7, the 'aragonite array' characterised by near-

constant $\mathrm{Sr} / \mathrm{Ca}$ ratios and variable $\mathrm{Mg} / \mathrm{Ca}$ ratios is therefore best explained by the contamination of aragonite minerals/concretions with variable amounts of clays. Similarly, bioclasts plot clearly on a mixing line between the biogenic calcite and detrital end-members (Fig. 7). 
The relationship between $\mathrm{Sr} / \mathrm{Ca}$ and $\mathrm{Mg} / \mathrm{Ca}$ values for authigenic carbonates (Fig. 7) shows that those ratios can be used to discriminate between aragonite, high-Mg carbonates, low-Mg calcite and terrigenous fractions in cold seep sediments. Assuming that those four components control the total budget of $\mathrm{Sr}, \mathrm{Mg}$ and $\mathrm{Ca}$ in Niger Delta sediments, a mixing model between can be used to quantify the proportion of authigenic carbonate phases in sediments. Here, low-Mg calcite refers to the biogenic polymorph that is generally formed by surface dwelling organisms (e.g. foraminifers), and is usually the only $\mathrm{CaCO}_{3}$ form found preserved in deepwater sediments. Note however that authigenic low-Mg calcite can also form in cold seep environments, but it is usually less abundant than other authigenic carbonate phases. Barite represents another possible significant source of $\mathrm{Sr}$ in cold seep sediments (e.g. Torres et al., 2002). But the low Ba contents measured in all our studied sediment and authigenic carbonate samples (from 50 to 800 ppm; Table 5) suggest that barite is not common in Niger fan sediments.

The $\mathrm{Sr} / \mathrm{Ca}$ and $\mathrm{Mg} / \mathrm{Ca}$ ratios for the end-members were derived directly from our $\mathrm{XRF}$ and electron microprobe data. We have considered that high-Mg calcite is most suitable for representing the 'high-Mg carbonate' end-member, because other Mg-rich carbonate phases (e.g. dolomite, siderite) are much less abundant in Niger Delta sediments, especially in the Pockmark area. The $\mathrm{Sr} / \mathrm{Ca}$ and $\mathrm{Mg} / \mathrm{Ca}$ ratios of a noncarbonated sediment sample $\left(\mathrm{N} 2-\mathrm{KS}-44 \_130 \mathrm{~cm}\right)$ were considered for the terrigenous end-member component in our study area (Table 5). The $\mathrm{Sr} / \mathrm{Ca}$ and $\mathrm{Mg} / \mathrm{Ca}$ ratios for the low-Mg calcite end-member (biogenic calcite) were inferred from our electron microprobe analyses of bioclasts. Those values are similar to those obtained on cleaned foraminifera and coccoliths (Rosenthal et al., 1997; Stoll and Schrag, 1999; Rickaby et al., 2002; Lear et al., 2002, 2003).

Our simple mixing model was defined by four mass balance equations ( $\mathrm{Sr}, \mathrm{Mg}, \mathrm{Ca}$, mass conservation equation) with four unknowns (i.e. the proportion of each of our four end-members), written and solved in matrix form. The validity of our method was tested by comparing our modelled data with direct XRD quantitative mineral analysis (XRD) on the same sediment powders. This was done on a series of various sediment samples 
collected from our studied areas (Fig. 8). Results show a very nice correlation between the two datasets, demonstrating that our approach is valid.

\subsection{Down-core variations of aragonite and high-Mg calcite contents}

In Fig. 9A, sediments recovered from the reference and Diapir areas, and the northern fault and southern pockmark zones (Pockmark area) plot on the mixing line between biogenic calcite and detrital end-members, defined previously in section 5.1. In contrast, many sediments recovered from the hydrate zone (Pockmark area) depart clearly from that mixing line (Fig. 9B), revealing the presence of discrete phases of aragonite and/or high-Mg carbonates in those sediments. Note that terrigenous sediments from the Mud Volcano area (core N1-KSF-12) exhibit lower Sr/Ca ratios than our detrital end-member (Fig. 9A). However, those mudflow sediments originate most likely from deep sedimentary units within the volcano plumbing system and, therefore, may not be representative of detrital sediments deposited on the Niger Delta during the recent Late Quaternary period.

Using our mixing model, we have calculated percentage contributions of each of the four end-member components to our studied sediments. Down-core variations of the modelled contents (wt \%) of aragonite and high-Mg calcite in core N2-KS-44 are displayed in Fig. 6. Our results indicate that core N2-KS-44 sediments contain up to $~ 20$ wt $\%$ of aragonite and $\sim 25 \mathrm{wt} \%$ of high- $\mathrm{Mg}$ calcite. Aragonite is encountered almost exclusively in sediments between $30 \mathrm{~cm}$ and $180 \mathrm{~cm}$ depth, whereas high- $\mathrm{Mg}$ calcite also occurs in deeper sediment layers ( $230 \mathrm{~cm} ; 260-280 \mathrm{~cm}$ depth). Similarly, core N1-KI27 from the hydrate zone also displays high proportions of aragonite ( 5-20 wt\%; not shown here) and high-Mg calcite ( 10-30 wt\%; not shown here), which can be unambiguously attributed to the presence of discrete concretions of authigenic carbonates at that site. In all other studied cores, modelled mineral values confirm that the absence of both aragonite and high- $\mathrm{Mg}$ calcite phases in sediments (not shown here). This indicates that no carbonate precipitation event has occurred within the studied sections of the cores investigated. To further confirm the validity of our approach, we have tested 
the sensitivity of our calculated aragonite and high-Mg calcite contents to changes in $\mathrm{Sr} / \mathrm{Ca}$ and $\mathrm{Mg} / \mathrm{Ca}$ ratios for all four end-members. An important result is that, however the $\mathrm{Sr} / \mathrm{Ca}$ and $\mathrm{Mg} / \mathrm{Ca}$ value used in our calculation is changed, the same down-core variations observed in Fig. 6 are maintained. By changing $\mathrm{Sr} / \mathrm{Ca}$ and $\mathrm{Mg} / \mathrm{Ca}$ ratios of our four end-members by $\pm 20 \%$ (see error bars in Fig. 7 and 9), a maximum variation of 20 $\%$ and $25 \%$ are calculated for high-Mg calcite and aragonite contents, respectively.

Several factors can explain the absence of authigenic carbonate phases in sediments (e.g. Luff et al., 2004): inactivity (or weak activity) of methane seepage at the sites investigated (such as for the reference cores for example), low dissolved methane contents in fluids, high bioturbation rates, high sedimentation rates and/or high fluid flow rates (such as perhaps for those cores from the northern fault zone). In addition, it is known that aragonite is the least stable carbonate mineral (Burton, 1993), which often dissolves and recrystallizes into calcite in sedimentary sequences. A recent modelling study (Luff et al., 2005) suggested that aragonite dissolution in cold seep environments initiates as soon as bicarbonate release from AOM into pore-waters is reduced. The absence of aragonite phases in core N2-KS-44 sediments below $180 \mathrm{~cm}$ depth could hence be due to aragonite dissolution. In marked contrast, Naehr et al. (2000) reported occurrence of aragonite-rich concretions down to $\sim 35 \mathrm{~m}$ below seafloor in Blake Ridge sediments. This shows that authigenic aragonite may be well preserved during burial in such cold seep settings. Therefore, it is unclear whether the absence of aragonite-rich concretions at sediment depths deeper than $180 \mathrm{~cm}$ in core N2-KS-44 was caused by post-depositional dissolution processes or, instead, simply reflects that aragonite precipitation never took place at these sediment depths. Additional studies will be needed to better constrain the extent to which aragonite-rich concretions may be preserved in hydrate-bearing sediments.

Overall, our results show clearly that discrete ( $\mu \mathrm{m}$ - to mm-size) authigenic carbonate phases precipitate within sediments in gas-hydrate-bearing areas, which can be easily detected using $\mathrm{Sr} / \mathrm{Ca}$ and $\mathrm{Mg} / \mathrm{Ca}$ ratios in bulk sediments. This shows that highresolution geochemical profiles along cold seep sediments can bring direct quantitative 
information on the presence of carbonate-rich layers related to methane seepage in marine sediments.

\subsection{Implications for authigenic carbonate genesis in cold seep sediments}

We have compared down-core profiles of our modelled authigenic carbonate contents with stable isotope ratios $\left(\delta^{18} \mathrm{O}, \delta^{13} \mathrm{C}\right)$ for core $\mathrm{N} 2-\mathrm{KS}-44$ (Fig. 6). The $\delta^{18} \mathrm{O}$ and $\delta^{13} \mathrm{C}$ values of bulk carbonate fractions represent a mixture between biogenic carbonates (e.g. foraminifers, bivalve shells) and authigenic carbonates. The large $\delta^{13} \mathrm{C}$ negative excursions observed throughout core $\mathrm{N} 2-\mathrm{KS}-44$ indicate that a significant fraction of carbonates in those sediments have precipitated from pore waters enriched in methanederived dissolved carbon pool. The $\delta^{13} \mathrm{C}$ negative excursions match perfectly with our modelled contents for aragonite and high-Mg calcite (see dashed lines in Fig. 6), confirming that those discrete carbonate phases do correspond to methane-derived carbonates. Modelled contents of biogenic calcite vary from $\sim-0.2$ to $8 \mathrm{wt} \%$ throughout core N2-KS-44 (Fig. 6). Between $30 \mathrm{~cm}$ and $180 \mathrm{~cm}$ down-core, biogenic calcite contents are consistently low $(<5 \%)$, indicating that a significant part of carbonates present at these sediment depths corresponds to authigenic carbonates (aragonite and high-Mg calcite). This suggests that the stable isotope signal associated with this sediment layer is dominated by methane-derived carbonates, in agreement with the observation that bulk carbonate fractions in those sediments display $\delta^{13} \mathrm{C}$ values (typically $-25 \%$ ) almost as negative as values measured in carbonate nodules $(-37 \%$ ).

In cold seep environments, it is commonly accepted that aragonite forms preferentially when the oxidation of methane-rich fluids occurs at proximity to seawater, in the near-seafloor environment (e.g. Ritger et al., 1987; Matsumoto, 1990; Bohrmann et al., 1998; Aloisi et al., 2000; Burton and Walker, 1987; Burton, 1993). Several studies have shown that aragonite precipitation is favoured over that of calcite at high $\mathrm{SO}_{4}{ }^{2-}$ concentrations (Burton and Walker, 1987; Burton, 1993), and when uprising methanerich fluids have a high velocity flow (Luff and Wallman, 2003). By contrast, high-Mg calcite precipitation may occur at various depths below the seafloor, in the sulphate 
reduction zone of marine sediments (e.g. Greinert et al., 2001; Gieskes et al., 2005). By analogy, the presence of discrete aragonite-rich phases in core N2-KS-44, between $30 \mathrm{~cm}$ and $180 \mathrm{~cm}$ depth, suggests that carbonate precipitation associated with these sediment layers has taken place near the seafloor.

At present, gas hydrates occur much deeper in the sediment column at that site, at $\sim 4$ $\mathrm{m}$ below the seafloor. Measurements of pore water sulphate contents along core N2-KS44 (not presented here) suggest that anaerobic oxidation of methane (AOM) takes place at $\sim 2.6 \mathrm{~m}$ below the seafloor (Bayon et al., submitted). This indicates that present-day carbonate formation at that site probably also occurs at around $2.6 \mathrm{~m}$ sediment depth, in response to high pore-water alkalinity. This is also supported by our modelled data, which reveal that high-Mg calcite occurs between 2.3 and $2.8 \mathrm{~m}$ depth in core N2-KS-44 sediments (Fig. 6). Therefore, it is very likely that those aragonite-rich sediment layers in core N2-KS-44 correspond to 'fossil' horizons of AOM events, which took place in the near seafloor environment.

\section{Summary}

Elemental and stable isotope data have been reported for authigenic carbonates and sediments from several cold seep environments in the Niger Delta deep province. Both $\mathrm{Sr} / \mathrm{Ca}$ and $\mathrm{Mg} / \mathrm{Ca}$ ratios exhibit large variations in studied authigenic carbonates and sediments, which reflect various contributions from terrigenous, biogenic and authigenic (i.e. aragonite, high-Mg calcite, dolomite, siderite) fractions. Elemental analyses of individual carbonate minerals reveal that contamination by clay material increases with decreasing carbonate grain-size. We show that $\mathrm{Sr} / \mathrm{Ca}$ and $\mathrm{Mg} / \mathrm{Ca}$ ratios can be used for identifying Sr-rich (aragonite) and Mg-rich (high-Mg calcite, dolomite) carbonate layers in cold seep sediments. Using $\mathrm{Sr} / \mathrm{Ca}$ and $\mathrm{Mg} / \mathrm{Ca}$ ratios, the proportion (wt \%) of authigenic carbonates in cold seep sediments can be quantified using a simple mixing model between four end-member components (aragonite, high-Mg calcite, biogenic calcite and detrital fraction). This model was tested successfully by comparing modelled data to direct quantitative XRD mineral analyses and applied to a series of sediment cores 
recovered from various cold seep settings (mud volcano, diaper, pockmark, gas hydratebearing sediments). Our results show that discrete phases of aragonite and high-Mg calcite occur in sediments from gas-hydrate-bearing areas. This is confirmed by the $\delta^{13} \mathrm{C}$ record for bulk carbonate fractions, which match perfectly with our modelled contents for aragonite and high-Mg calcite. Overall, our results suggest that $\mathrm{Sr} / \mathrm{Ca}$ and $\mathrm{Mg} / \mathrm{Ca}$ ratios have great potential for identifying present and fossil AOM horizons in marine sediments.

\section{Acknowledgements}

The authors thank all the crew on-board of RV Suroît and RV Atalante. Gideon Henderson and Norman Charnley are warmly thanked for giving access to the electron microprobe analyser at Oxford University and providing assistance during analyses. We also thank Jens Greinert and one anonymous reviewer for many constructive comments and suggestions. This work was funded by Ifremer and Total, through the NERIS project. 


\section{References}

Aloisi, G., Pierre, C., Rouchy, J.-M., Foucher, J.-P., Woodside, J., the MEDINAUT Scientific Party, 2000. Methane-related authigenic carbonates of eastern Mediterranean Sea mud volcanoes and their possible relation to gas hydrate destabilisation. Earth Planet. Sci. Lett. 184, 321-338.

Bayon, G., Henderson, G. M., Pierre, C., Caprais, J.-C., Cauquil, E., Etoubleau, J., Fouquet, Y., Marsset, T., Pignet, P., Sultan, N., Voisset., M. Gas hydrate dynamics in Niger Delta sediments inferred from U/Th dating of cold-seep carbonates. Submitted.

Boetius, A., Ravenschlag, K., Schubert, C.J., Rickert, D., Widdel, F., Gieseke, A., Amann, R., Jorgensen, B.B., Witte, U., Pfannkuche, O., 2000. A marine microbial consortium apparently mediating anaerobic oxidation of methane. Nature 407, 623626.

Bohrmann, G., Meinert, J., Suess, E., Torres, M., 1998. Authigenic carbonates from the Cascadia subduction zone and their relation to gas hydrate stability. Geology 26, 647650 .

Brooks, J. M., Anderson, A. L., Sassen, R., MacDonald, I. R., Kennicutt, II M. C., Guinasso Jr., N. L., 1994. Hydrate occurrences in shallow subsurface cores from continental slope sediments. In Annals of the New York Academy of Sciences 715, 381-391.

Burke, K., 1972. Longshore drift, submarine canyons, and submarine fans in development of Niger Delta. Bull. Am. Assoc. Petrol. Geol. 56, 1975-1983.

Burton, E. A., Walker, L. M., 1987. Relative precipitation rates of aragonite and Mg calcite from seawater: Temperature or carbonate ion control? Geology 15, 111-114.

Burton, E. A., 1993. Controls on marine carbonate cement mineralogy: review and reassessment. Chem. Geol. 105, 163-179.

Cohen, H. A., McClay, K., 1996. Sedimentation and shale tectonism of the southwestern Niger Delta front. Mar. Petrol. Geol. 13, 313-329.

Gieskes, J., Mahn, C., Day, S., Martin, J. B., Greinert, J., Rathburn, T., MacAdoo, B., 2005. A study of the chemistry of pore fluids and authigenic carbonates in methane 
seep environments: Kodiak Trench, Hydrate Ridge, Monterey Bay, and Eel River Basin. Chem. Geol. 220, 329-345.

Greinert, J., Bohrmann G., Suess, E., 2001. Gas hydrate-associated carbonates and methane venting at Hydrate Ridge: Classification, distribution and origin of carbonate lithologies. In Natural Gas Hydrates: Occurrence, Distribution and Detection (ed. Paull C. K. and Dillon W. P.), Vol. 124, pp. 99-113, American Geophysical Union.

Hovland, M., Talbot, M.R., Qvale, H., Olaussen, S., Aasberg, L. 1997. Methane-related carbonate cements in pockmarks of the North Sea. J. Sedim. Petrol. 57, 881-892.

Huguen, C., 2003. Characterization and classification of fluid expulsion structures on the seafloor - Relationships with geologic structure (surface and subsurface), Internal Report TOTAL, 33p.

Jansen, J.H.F., Van der Gaast, S.J., Koster, B., Vaars, A.J., 1998. CORTEX, a shipboard XRF-scanner for element analyses in split sediment cores. Mar. Geol. 151, 143-153.

Koshikawa, T, Kido, Y., Tada, R., 2003. High-resolution rapid elemental analysis using an XRF microscanner. J. Sediment. Res. 73, 824-829.

Lear, C. H., Rosenthal, Y., Slowey, N. 2002. Benthic foraminiferal Mg/Capaleothermometry: A revised core-top calibration. Geochimica et Cosmochimica Acta 66, 3375-3387.

Lear, C.H., Elderfield, H., Wilson, P. A., 2003. A Cenozoic seawater Sr/Ca record from benthic foraminiferal calcite and its application in determining global weathering fluxes. Earth and Planetary Science Letters 208, 69-84.

Luff, R., Wallmann, K., 2003. Fluid flow, methane fluxes, carbonate precipitation and biogeochemical turnover in gas hydrate-bearing sediments at Hydrate Ridge, Cascadia Margin: numerical modelling and mass balances, Geochim. Cosmochim. Acta 67, 3403-3421.

Luff, R., Wallmann, K., Aloisi, G., 2004. Physical and biogeochemical constraints on carbonate crust formation at cold vent sites: significance for fluid and methane budgets and chemosynthetic biological communities. Earth Planet. Sci. Lett. 221, 337-353. 
Luff, R., Greinert, J., Wallmann, K., Klaucke, I., Suess, E., 2005. Simulation of longterm feedbacks from authigenic carbonate crust formation at cold vent sites. Chem. Geol. 216, 157-174.

Marsset, T., Marsset, B., Vagner, P., Sultan, N., Voisset, M., Cauquil, E. Geohazard investigation on the Niger continental slope: New insights from near bottom geophysics. Submitted.

Mascle, J., Bornhold, B. D., Renard, V. 1973. Diapiric structures off Niger delta. Amer. Assoc. Petrol. Geol. Bull. 57, 1672-1678.

Matsumoto, R., 1989. Isotopically heavy oxygen- containg siderite derived from the decomposition of methane hydrate. Geology 17, 707-711.

Matsumoto, R., 1990. Vuggy carbonate crust formed by hydrocarbon seepage on the continental shelf of Baffin Island, northeast Canada. Geochem. J. 24, 143-158.

Marsset, T., Marsset, B., Vagner, P., Sultan, N., Voisset, M., Cauquil, E., 2005. Geohazard investigation on the Niger continental slope: new insights from near bottom geophysics, in: Voisset, M., Cauquil, E., Sultan, N., Marsset, T., Vagner, P., Bayon, G., Vernant, A.M., Le Drezen, E., Harmegnies, F., Fouquet, Y., Etoubleau. Confidential Report Neris, Codicil 1, Ifremer-Total nº3/1.214.722/BF.

Mazzini, A., Ivanov, M. K., Parnell, J., Stadnitskaia, A., Cronin, B. T., Poludetkina, E., Mazurenko, L., van Weering, T. C. E., 2004. Methane-related authigenic carbonates from the Black Sea: geochemical characterisation and relation to seeping fluids. Mar. Geol. 212, 153-181.

Naehr, T. H., Rodriguez, N. M., Bohrmann, G., Paull, C. K., Botz, R., 2000. Methanederived authigenic carbonates associated with gas hydrate decomposition and fluid venting above the Blake Ridge Diapir. Proc. ODP Sci. Results 164, 286-300.

Orphan, V.J., Ussler, W., Naehr, T.H., House, C.H., Hinrichs, K.-U., Paull, C.K., 2004. Geological, geochemical, and microbiological heterogeneity of the seafloor around methane vents in the Eel River Basin, offshore California. Chem. Geol. 205, 265289. 
Pierre, C., Rouchy, J. M., Gaudichet, A., 2000. Diagenesis in the gas hydrate sediments of the Blake Ridge. Mineralogy and stable isotope compositions of the carbonate and sulphide minerals. Proc. ODP Sci. Results 164, 139-145.

Rickaby, R. E. M., Schrag, D. P., Zondervam, I., Riebesell, U., 2002. Growth rate dependence on $\mathrm{Sr}$ incorporation during calcification of Emiliana huxleyi. Global Biogeochem. Cycles 16, 1006, doi:10.1029/2001GB001408.

Ritger, S., Carson, B., Suess, E., 1987. Methane-derived authigenic carbonates formed by subduction-induced pore-water expulsion along the Oregon/Washington margin. Geol. Soc. Am. Bull. 98, 147-156.

Rodriguez, N. M., Paull, C. K., Borowski, W. S., 2000. Zonation of authigenic carbonates within gas hydrate-bearing sedimentary sections on the Blake Rige: offshore southeastern North America. Proc. ODP Sci. Results 164, 301-313.

Rosenthal, Y., Boyle, E. A., Slowey, N., 1997. Temperature control on the incorporation of magnesium, strontium, fluorine, and cadmium into benthic foraminiferal shells from Little Bahama Bank: Prospects for thermocline paleoceanography. Geochim. Cosmochim. Acta 61, 3633-3643.

Stoll, H. M., Schrag, D., 1999. Coccolith $\mathrm{Sr} / \mathrm{Ca}$ as a new indicator of coccolothophorid calcification and growth rate. Geochem. Geophys. Geosyst. 1, doi:10.1029/1999GC000015

Torres, M. E., McManus, J., Huh, C.-A., 2002. Fluid seepage along the San Clemente Fault scarp: basin-wide impact on barium cycling. Earth Planet. Sci. Lett. 203, 181194.

Zabel, M., Schneider, R. R., Wagner, T., Adegbie, A. T., de Vries, U., Kolonic, S. 2001. Late Quaternary climate changes in central Africa as inferred from terrigeneous input to the Niger Fan. Quat. Res. 56, 207-217. 


\section{Figure legends}

\section{Figure 1}

Location of the study area on the Niger Delta deep province

\section{Figure 2}

Study area on the Niger Delta deep province with positions of the cores discussed in the text.

\section{Figure 3}

Photographs of authigenic carbonates from the Niger Fan. Nodules of siderite (Mud Volcano); dolomite nodule (Diapir area); chemoherm carbonates (Diapir area and northern fault zone, Pockmark area); carbonate-cemented breccias and gas hydrate carbonate (Hydrate zone).

\section{Figure 4}

Mini pellet (200 mg) XRF data versus conventional (bead) XRF data for Niger Fan sediments. Least squares regression lines are shown with the $95 \%$ prediction intervals. The standard error of the estimate ( 2 see) is a measure of the accuracy of predictions made with regression lines.

\section{Figure 5}

Down-core profiles of $\mathrm{CaO}$ (wt\%), $\mathrm{Sr}(\mathrm{ppm}), \mathrm{MgO}$ (wt\%), $\mathrm{Sr} / \mathrm{Ca}$ and $\mathrm{Mg} / \mathrm{Ca}$ (wt ratios) for $\mathrm{A}$ ) Interface cores from the Reference (N1-KI-04, N2-KI-13) and Diapir (N1-KI-47) areas; B) Interface cores from the Pockmark area (N2-KI-20, N2-KI-28, N2-KI-32, N1-KI-27) and C) Kullenberg cores (N1-KSF-12, N2-KS-44).

\section{Figure 6}

Down-core profiles of stable isotope ratios, $\mathrm{Sr} / \mathrm{Ca}$ and $\mathrm{Mg} / \mathrm{Ca}$ (wt ratio), and modelled aragonite, high-Mg calcite and biogenic calcite contents (wt \%) for core N2-KS-44 (Hydrate zone, Pockmark area). The $\delta^{13} \mathrm{C}$ negative excursions match perfectly with modelled contents for aragonite and high-Mg calcite (see dashed lines). The high $\mathrm{Sr} / \mathrm{Ca}$ and $\mathrm{Mg} / \mathrm{Ca}$ ratios at 130 $\mathrm{cm}$ and below $300 \mathrm{~cm}$ correspond to layers of carbonate-poor detrital sediments.

\section{Figure 7}


Relationship between $\mathrm{Sr} / \mathrm{Ca}$ and $\mathrm{Mg} / \mathrm{Ca}$ (wt ratio) in cold seep carbonate concretions and authigenic minerals. The dashed lines correspond to mixing lines between hypothetical endmembers (aragon ite, high-Mg calcite, biogenic calcite, detrital).

\section{Figure 8}

Direct quantitative XRD data versus modelled mineral contents (using $\mathrm{Sr} / \mathrm{Ca}$ and $\mathrm{Mg} / \mathrm{Ca}$ ratios) for aragonite and high-Mg calcite in Niger Fan sediments (core N2-KS-44).

\section{Figure 9}

Relationship between $\mathrm{Sr} / \mathrm{Ca}$ and $\mathrm{Mg} / \mathrm{Ca}$ (wt ratio) in Niger Delta sediments. A. Sediments from reference, Diapir, Mud Volcano, and Pockmark (southern pockmark and northern fault zones) areas. B. Sediments from the hydrate zone (Pockmark area). The dashed lines correspond to mixing lines between hypothetical end-members (aragonite, high-Mg calcite, biogenic calcite, detrital). 
Click here to download Table: Table1.pdf

Table 1. Lengths and water depths of the cores investigated

\begin{tabular}{|c|c|c|c|}
\hline Core & Core type & $\begin{array}{l}\text { Length } \\
(\mathrm{m})\end{array}$ & $\begin{array}{c}\text { Water depth } \\
(\mathrm{m})\end{array}$ \\
\hline \multicolumn{4}{|c|}{ Mud volcano area } \\
\hline N1-KSF-12 & Kullenberg & 4.0 & 1396 \\
\hline N1-KS-13 & Kullenberg & 2.8 & 1380 \\
\hline \multicolumn{4}{|c|}{$\begin{array}{l}\text { Pockmark area } \\
\text { northern fault zone }\end{array}$} \\
\hline N1-KS-22 & Kullenberg & 3.0 & 1150 \\
\hline N1-KSF-28 & Kullenberg & 4.7 & 1152 \\
\hline $\mathrm{N} 2-\mathrm{KI}-32$ & Interface & 0.79 & 1149 \\
\hline \multicolumn{4}{|c|}{ southern fault zone } \\
\hline N1-KS-29 & Kullenberg & 2.5 & 1233 \\
\hline N2-KI-28 & Interface & 0.70 & 1229 \\
\hline \multicolumn{4}{|c|}{ hydrate zone } \\
\hline N1-KSF-23 & Kullenberg & 2.0 & 1147 \\
\hline N1-KI-27 & Interface & 0.25 & 1147 \\
\hline N1-KSF-20 & Kullenberg & 3.0 & 1180 \\
\hline N1-KI-26 & Interface & 0.60 & 1182 \\
\hline N1-KS-36 & Kullenberg & 3.7 & 1200 \\
\hline N1-KSF-37 & Kullenberg & 7.0 & 1203 \\
\hline N2-KS-44 & Kullenberg & 6.6 & 1174 \\
\hline $\mathrm{N} 2-\mathrm{KI}-20$ & Interface & 0.88 & 1174 \\
\hline \multicolumn{4}{|l|}{ Diapir area } \\
\hline N2-DR-51 & Dredge & - & $\sim 1640$ \\
\hline N1-KS-07 & Kullenberg & 0.20 & 1633 \\
\hline N1-KSF-45 & Kullenberg & 1.9 & 1546 \\
\hline N1-KI-47 & Interface & 0.45 & 1540 \\
\hline \multicolumn{4}{|c|}{ Reference areas } \\
\hline N1-KI-04 & Interface & 0.80 & 1695 \\
\hline N2-KI-13 & Interface & 0.45 & 1212 \\
\hline
\end{tabular}


Table 2. Description and mineralogy of Niger Fan authigenic carbonates

\begin{tabular}{|c|c|c|c|c|c|}
\hline Core & $\begin{array}{c}\text { Depth } \\
\text { b.s.f }(\mathrm{cm})\end{array}$ & Type & $\begin{array}{c}\text { Dominant } \\
\text { mineral }\end{array}$ & Description & $\begin{array}{l}\text { Size } \\
(\mathrm{cm})\end{array}$ \\
\hline \multicolumn{6}{|c|}{ Mud volcano area } \\
\hline N1-KSF-12 & $400 \mathrm{a}$ & mudstone & $\begin{array}{c}\text { siderite, } \\
\text { hydroxyapatite }\end{array}$ & beige slab & $2 \mathrm{~cm}$ \\
\hline- & $400 \mathrm{~b}$ & mudstone & siderite & homogeneous nodules & $3 \mathrm{~cm}$ \\
\hline - & $400 \mathrm{c}$ & mudstone & high-Mg calcite & homogeneous nodule & $3 \mathrm{~cm}$ \\
\hline N1-KS-13 & 100 & mudstone & siderite & homogeneous nodules & $2 \mathrm{~cm}$ \\
\hline - & 280 & mudstone & $\begin{array}{l}\text { quartz, kaolinite, } \\
\text { dolomite }\end{array}$ & $\begin{array}{c}\text { friable, carbonate-cemented } \\
\text { sediment }\end{array}$ & $3 \mathrm{~cm}$ \\
\hline \multicolumn{6}{|l|}{ Diapir area } \\
\hline N1-KSF-45 & 95,185 & mudstone & dolomite & homogeneous nodules & $4-8 \mathrm{~cm}$ \\
\hline N1-KI-47 & 12,27 & mudstone & dolomite & homogeneous nodules & $2 \mathrm{~cm}$ \\
\hline N2-DR-51 & seafloor & chemoherm & aragonite & intraformational breccias & $50 \mathrm{~cm}$ \\
\hline N1-KS-07 & $0-20$ & chemoherm & aragonite & intraformational breccias & $10 \mathrm{~cm}$ \\
\hline \multicolumn{6}{|c|}{$\begin{array}{l}\text { Pockmark area } \\
\text { northern fault zone }\end{array}$} \\
\hline N1-KS-22 & $210-300$ & chemoherm & aragonite & intraformational breccias & $10 \mathrm{~cm}$ \\
\hline N1-KSF-28 & 470 & chemoherm & aragonite & intraformational breccias & $2 \mathrm{~cm}$ \\
\hline \multicolumn{6}{|c|}{ southern pockmark zone } \\
\hline N1-KS-29 & 71 & mudstone & $\begin{array}{l}\text { high-Mg calcite } \\
\text { calcite }\end{array}$ & homogeneous nodules & $8 \mathrm{~cm}$ \\
\hline \multicolumn{6}{|c|}{ hydrate zone } \\
\hline N1-KSF-23 & $0-155$ & mudstone & aragonite & mudclast breccias & $<2 \mathrm{~cm}$ \\
\hline $\mathrm{N} 1-\mathrm{KI}-27$ & $0-25$ & mudstone & aragonite & mudclast breccias & $<2 \mathrm{~cm}$ \\
\hline N1-KI-26 & 60 & mudstone & aragonite & gas hydrate carbonate & $8 \mathrm{~cm}$ \\
\hline N1-KS-36 & $70-215$ & mudstone & high-Mg calcite & mudclast breccias & $<8 \mathrm{~cm}$ \\
\hline N1-KSF-37 & $28-200$ & mudstone & high-Mg calcite & mudclast breccias & $<6 \mathrm{~cm}$ \\
\hline N2-KS-44 & $30-260$ & mudstone & $\begin{array}{l}\text { aragonite, } \\
\text { high-Mg calcite }\end{array}$ & mudclast breccias & $<4 \mathrm{~cm}$ \\
\hline
\end{tabular}


Table 3. Major element composition of Niger Fan authigenic carbonates

\begin{tabular}{|c|c|c|c|c|c|c|c|c|c|c|c|c|c|c|c|c|c|}
\hline Core & $\begin{array}{l}\text { Depth } \\
(\mathrm{cm})\end{array}$ & $\begin{array}{c}\text { Dominant } \\
\text { mineral }\end{array}$ & $\begin{array}{c}\mathrm{SiO} 2 \\
\% \\
\end{array}$ & $\begin{array}{c}\mathrm{Al} 2 \mathrm{O} 3 \\
\% \\
\end{array}$ & $\begin{array}{c}\mathrm{Fe} 2 \mathrm{O} 3 \\
\% \\
\end{array}$ & $\begin{array}{c}\mathrm{MnO} \\
\% \\
\end{array}$ & $\begin{array}{c}\mathrm{MgO} \\
\% \\
\end{array}$ & $\begin{array}{c}\mathrm{CaO} \\
\% \\
\end{array}$ & $\begin{array}{c}\mathrm{Na} 2 \mathrm{O} \\
\% \\
\end{array}$ & $\begin{array}{c}\mathrm{K} 2 \mathrm{O} \\
\%\end{array}$ & $\begin{array}{c}\mathrm{TiO} 2 \\
\% \\
\end{array}$ & $\begin{array}{c}\mathrm{P} 2 \mathrm{O} 5 \\
\% \\
\end{array}$ & $\begin{array}{c}\text { SO4 } \\
\% \\
\end{array}$ & LOI & Total & $\begin{array}{c}\mathrm{Ba} \\
\mathrm{ppm}\end{array}$ & $\begin{array}{c}\mathrm{Sr} \\
\mathrm{ppm}\end{array}$ \\
\hline \multicolumn{18}{|c|}{ Mud volcano area } \\
\hline N1-KSF-12 & $400 \mathrm{a}$ & $\begin{array}{c}\text { siderite, } \\
\text { hydroxyapatite }\end{array}$ & 7.40 & 3.64 & 23.21 & 0.59 & 16.39 & 10.09 & 0.68 & 0.06 & 0.06 & 6.39 & $<0.10$ & 30.87 & 99.37 & 139 & 286 \\
\hline- & $400 \mathrm{~b}$ & high-Mg calcite & 16.61 & 7.65 & 36.18 & 0.46 & 7.68 & 2.76 & 0.68 & 0.34 & 0.44 & 0.46 & $<0.10$ & 27.08 & 100.35 & 110 & 122 \\
\hline- & $400 \mathrm{c}$ & siderite & 15.47 & 3.86 & 4.75 & 0.35 & 16.02 & 22.55 & 0.39 & 0.15 & 0.16 & 0.14 & 0.53 & 34.93 & 99.30 & 68 & 486 \\
\hline N1-KS-13 & 100 & siderite & 13.91 & 6.77 & 35.48 & 1.72 & 7.14 & 3.30 & 1.50 & 0.40 & 0.33 & 0.40 & $<0.10$ & 29.76 & 100.71 & 82 & 117 \\
\hline- & 280 & quartz, dolomite & 60.24 & 12.06 & 4.80 & 0.07 & 7.17 & 2.08 & 0.81 & 0.82 & 0.67 & $<0.10$ & 0.27 & 10.62 & 99.61 & 83 & 110 \\
\hline \multicolumn{18}{|l|}{ Diapir area } \\
\hline N1-KSF-45 & 185 & dolomite & 8.42 & 3.73 & 1.39 & 0.06 & 13.10 & 31.30 & 0.23 & 0.31 & 0.16 & $<0.10$ & 1.73 & 39.38 & 99.81 & 189 & 324 \\
\hline $\mathrm{N} 1-\mathrm{KI}-47$ & 12 & dolomite & 20.30 & 7.63 & 8.17 & 0.22 & 8.29 & 22.25 & 0.71 & 0.97 & 0.27 & 0.18 & 5.58 & 25.61 & 100.19 & $<100$ & 247 \\
\hline \multicolumn{18}{|c|}{ Pockmark area } \\
\hline \multicolumn{18}{|c|}{ Northern fault zone } \\
\hline N1-KS-22 & 300 & aragonite & 8.64 & 3.89 & 1.45 & 0.02 & 4.21 & 35.04 & 0.35 & 0.22 & 0.15 & 0.18 & 1.98 & 43.08 & 99.21 & 30 & 7042 \\
\hline N1-KSF-28 & 470 & aragonite & 4.59 & 2.01 & 2.05 & 0.00 & 0.12 & 49.20 & 0.30 & 0.10 & 0.07 & 0.03 & 5.79 & 35.63 & 99.89 & $<100$ & 6355 \\
\hline \multicolumn{18}{|c|}{ Southern pockmarks } \\
\hline N1-KS-29 & 71 & high-Mg calcite & 10.76 & 5.32 & 3.94 & 0.02 & 4.14 & 35.85 & 0.47 & 0.33 & 0.19 & 0.31 & 8.79 & 30.08 & 100.21 & $<100$ & 680 \\
\hline \multicolumn{18}{|c|}{ Hydrate zone } \\
\hline N1-KSF-23 & 125 & aragonite & 5.11 & 2.57 & 0.91 & 0.00 & 0.30 & 48.23 & 0.39 & 0.15 & 0.09 & 0.04 & 5.09 & 36.65 & 99.53 & $<100$ & 6985 \\
\hline $\mathrm{N} 1-\mathrm{KI}-26$ & 60 & aragonite & 11.51 & 5.38 & 1.92 & 0.01 & 0.96 & 40.12 & 1.01 & 0.24 & 0.19 & $<0.10$ & 1.93 & 35.75 & 99.01 & 98 & 5538 \\
\hline N1-KI-27 & 25 & aragonite & 5.63 & 2.49 & 0.86 & 0.01 & 2.98 & 45.02 & 0.38 & 0.15 & 0.09 & $<0.10$ & 0.92 & 40.51 & 99.03 & 235 & 5168 \\
\hline N1-KS-36 & 132 & high-Mg calcite & 6.17 & 3.25 & 1.32 & 0.00 & 6.84 & 40.10 & 0.30 & 0.15 & 0.11 & 0.06 & 6.20 & 36.28 & 100.79 & $<100$ & 826 \\
\hline- & 211 & high-Mg calcite & 9.81 & 4.75 & 1.87 & 0.00 & 5.07 & 38.46 & 0.43 & 0.20 & 0.16 & 0.05 & 3.22 & 35.66 & 99.70 & $<100$ & 968 \\
\hline N1-KSF-37 & 28 & high-Mg calcite & 7.73 & 3.86 & 1.64 & 0.00 & 6.37 & 39.46 & 0.27 & 0.13 & 0.14 & 0.08 & 4.49 & 36.04 & 100.21 & $<100$ & 776 \\
\hline- & 100 & high-Mg calcite & 10.74 & 4.72 & 1.64 & 0.03 & 13.97 & 27.45 & 0.39 & 0.32 & 0.20 & $<0.10$ & 0.65 & 38.96 & 99.06 & 291 & 727 \\
\hline- & 200 & high-Mg calcite & 11.66 & 5.15 & 1.77 & 0.01 & 5.51 & 36.07 & 0.54 & 0.23 & 0.20 & $<0.10$ & 1.15 & 37.02 & 99.31 & 151 & 1056 \\
\hline N2-KS-44 & 150 & aragonite & 4.30 & 2.16 & 0.80 & 0.00 & 1.17 & 48.33 & 0.40 & 0.09 & 0.07 & 0.03 & 2.32 & 39.39 & 99.05 & $<100$ & 6312 \\
\hline- & 150 & high-Mg calcite & 6.72 & 3.31 & 1.24 & 0.00 & 6.85 & 40.16 & 0.31 & 0.19 & 0.12 & 0.06 & 2.48 & 38.67 & 100.10 & $<100$ & 805 \\
\hline
\end{tabular}


Table 4. Representative electron microprobe analyses of various carbonate phases in mudclast breccias (core N2-KS-44)

\begin{tabular}{|c|c|c|c|c|c|c|c|c|c|c|c|c|}
\hline & $\begin{array}{c}\mathrm{O} \\
\text { wt } \%\end{array}$ & $\begin{array}{c}\mathrm{C} \\
\text { wt } \%\end{array}$ & $\begin{array}{c}\mathrm{S} \\
\text { wt } \%\end{array}$ & $\begin{array}{c}\mathrm{Ca} \\
\text { wt } \%\end{array}$ & $\begin{array}{c}\mathrm{Sr} \\
\text { wt \% }\end{array}$ & $\begin{array}{c}\mathrm{Si} \\
\text { wt \% }\end{array}$ & $\begin{array}{c}\mathrm{Fe} \\
\text { wt \% }\end{array}$ & $\begin{array}{c}\mathrm{Ti} \\
\text { wt } \%\end{array}$ & $\begin{array}{c}\mathrm{K} \\
\text { wt \% }\end{array}$ & $\begin{array}{c}\mathrm{Mg} \\
\text { wt \% }\end{array}$ & $\begin{array}{c}\text { Al } \\
\text { wt \% }\end{array}$ & $\begin{array}{l}\text { Total } \\
\text { wt } \%\end{array}$ \\
\hline \multicolumn{13}{|c|}{ Aragonite cement } \\
\hline Ac1 & 45.74 & 11.82 & 0.04 & 32.82 & 0.87 & 3.10 & 0.76 & 0.07 & 0.20 & 0.47 & 1.78 & 97.67 \\
\hline Ac2 & 47.57 & 9.32 & 0.16 & 32.28 & 0.93 & 3.78 & 0.87 & 0.10 & 0.23 & 0.37 & 2.15 & 97.76 \\
\hline Ac3 & 47.66 & 13.20 & 0.03 & 33.48 & 0.82 & 3.22 & 0.29 & 0.03 & 0.14 & 0.09 & 1.30 & 100.27 \\
\hline Ac4 & 44.28 & 16.59 & 0.05 & 32.90 & 0.80 & 2.07 & 0.47 & 0.02 & 0.15 & 0.14 & 1.00 & 98.46 \\
\hline Ac5 & 45.66 & 13.76 & 0.02 & 34.44 & 0.85 & 1.72 & 0.46 & 0.03 & 0.18 & 0.13 & 1.01 & 98.26 \\
\hline Ac6 & 45.88 & 14.16 & 0.03 & 33.45 & 0.80 & 2.02 & 0.53 & 0.05 & 0.16 & 0.16 & 1.19 & 98.43 \\
\hline Ac7 & 45.83 & 13.28 & 0.02 & 33.99 & 0.76 & 1.83 & 0.42 & 0.05 & 0.12 & 0.14 & 1.02 & 97.45 \\
\hline Ac8 & 41.73 & 22.35 & 0.03 & 27.23 & 0.62 & 3.09 & 0.71 & 0.09 & 0.18 & 0.28 & 1.51 & 97.83 \\
\hline Ac9 & 45.98 & 10.93 & 0.05 & 34.99 & 0.85 & 1.93 & 0.44 & 0.03 & 0.15 & 0.60 & 1.31 & 97.26 \\
\hline Ac10 & 46.83 & 10.90 & 0.04 & 34.91 & 0.79 & 2.68 & 0.35 & 0.07 & 0.11 & 0.18 & 0.97 & 97.83 \\
\hline Ac11 & 44.99 & 11.68 & 0.05 & 31.43 & 0.57 & 4.99 & 0.55 & 0.09 & 0.13 & 1.32 & 1.29 & 97.09 \\
\hline Ac12 & 45.81 & 10.40 & 0.67 & 34.29 & 0.95 & 2.43 & 1.00 & 0.06 & 0.21 & 0.17 & 1.48 & 97.46 \\
\hline Ac13 & 48.59 & 10.76 & 0.38 & 34.28 & 0.97 & 2.49 & 0.84 & 0.04 & 0.17 & 0.21 & 1.40 & 100.12 \\
\hline Ac14 & 47.48 & 10.26 & 0.08 & 33.16 & 0.80 & 2.42 & 0.59 & 0.05 & 0.18 & 1.15 & 1.43 & 97.59 \\
\hline Ac15 & 46.85 & 10.36 & 0.43 & 31.37 & 0.91 & 3.50 & 1.05 & 0.13 & 0.24 & 1.03 & 2.08 & 7.95 \\
\hline \multicolumn{13}{|c|}{ Botryoidal aragonite } \\
\hline Ab1 & 46.17 & 11.44 & 0.02 & 38.97 & 0.72 & 0.00 & 0.03 & 0.00 & 0.01 & 0.01 & 0.02 & 97.37 \\
\hline$A b 2$ & 46.62 & 10.90 & 0.04 & 35.95 & 0.84 & 1.31 & 0.26 & 0.02 & 0.15 & 0.28 & 1.06 & 97.43 \\
\hline Ab3 & 45.16 & 12.86 & 0.06 & 34.58 & 0.84 & 1.98 & 0.47 & 0.07 & 0.14 & 0.12 & 1.24 & 97.52 \\
\hline Ab4 & 46.32 & & 0.05 & 38.09 & 0.99 & 0.57 & 0.13 & 0.01 & 0.05 & 0.06 & 35 & 7.58 \\
\hline Ab5 & 45.40 & 12.38 & 0.12 & 33.62 & 0.86 & 2.41 & 0.60 & 0.08 & 0.16 & 0.17 & 1.60 & 97.40 \\
\hline Ab6 & 46.49 & 12.53 & 0.04 & 35.36 & 0.91 & 1.74 & 0.38 & 0.06 & 0.14 & 0.12 & 1.03 & 98.79 \\
\hline$A b 7$ & 46.35 & & 0.07 & & & 2.00 & 0.48 & 0.03 & & 0.13 & 0 & 8.02 \\
\hline Ab8 & 45.42 & 12.74 & 0.03 & 38.25 & 0.78 & 0.00 & 0.03 & 0.01 & 0.01 & 0.02 & 0.01 & 97.29 \\
\hline Ab9 & 46.78 & 12.04 & 0.01 & 38.08 & 0.77 & 0.00 & 0.04 & 0.00 & 0.00 & 0.01 & 0.00 & 97.73 \\
\hline Ab10 & 49.14 & 11.39 & 0.10 & 30.93 & 0.75 & 3.27 & 0.71 & 0.04 & 0.20 & 1.38 & 0.00 & 97.91 \\
\hline Ab11 & 47.00 & 10.67 & 0.04 & 34.80 & 0.85 & 1.74 & 0.47 & 0.00 & 0.14 & 1.14 & 1.12 & 97.97 \\
\hline \multicolumn{13}{|c|}{ Fibrous aragonite } \\
\hline Af1 & 46.22 & 11.94 & 0.02 & 38.42 & 0.61 & 0.00 & 0.01 & 0.00 & 0.00 & 0.02 & 0.13 & 97.36 \\
\hline Af2 & 46.02 & 11.69 & 0.02 & 36.66 & 1.17 & 0.77 & 0.16 & 0.03 & 0.06 & 0.05 & 0.52 & 97.15 \\
\hline Af3 & 45.57 & 12.33 & 0.01 & 37.91 & 1.17 & 0.00 & 0.00 & 0.00 & 0.02 & 0.01 & 0.05 & 97.07 \\
\hline Af4 & 43.37 & 16.04 & 0.03 & 37.60 & 1.07 & 0.00 & 0.00 & 0.01 & 0.01 & 0.02 & 0.01 & 98.15 \\
\hline Af5 & 46.27 & 11.73 & 0.02 & 38.75 & 0.89 & 0.00 & 0.03 & 0.00 & 0.02 & 0.01 & 0.08 & 97.79 \\
\hline Af6 & 47.17 & 12.28 & 0.02 & 39.16 & 1.03 & 0.07 & 0.04 & 0.00 & 0.03 & 0.02 & 0.16 & 99.99 \\
\hline Af7 & 46.11 & 11.49 & 0.00 & 39.13 & 0.95 & 0.00 & 0.01 & 0.00 & 0.02 & 0.01 & 0.01 & 97.71 \\
\hline Af8 & 47.94 & 11.17 & 0.04 & 36.01 & 0.89 & 0.88 & 0.18 & 0.00 & 0.04 & 1.10 & 0.75 & 99.00 \\
\hline Af9 & 47.71 & 10.77 & 0.05 & 35.68 & 0.86 & 2.13 & 0.32 & 0.07 & 0.36 & 0.09 & 1.02 & 99.05 \\
\hline Af10 & 46.52 & 11.28 & 0.10 & 35.83 & 1.17 & 1.44 & 0.38 & 0.01 & 0.09 & 0.13 & 0.93 & 97.88 \\
\hline \multicolumn{13}{|c|}{ High-Mg calcite } \\
\hline Mg1 & 40.93 & 23.86 & 0.07 & 23.87 & 0.08 & 3.12 & 0.09 & 0.07 & 0.22 & 3.49 & 1.80 & 98.39 \\
\hline Mg2 & 45.55 & 18.00 & 0.05 & 24.59 & 0.09 & 3.91 & 0.73 & 0.06 & 0.21 & 3.28 & 2.84 & 99.31 \\
\hline Mg3 & 46.32 & 14.77 & 0.06 & 30.38 & 0.11 & 1.22 & 0.34 & 0.02 & 0.09 & 3.80 & 0.72 & 97.82 \\
\hline Mg4 & 45.42 & 15.20 & 0.07 & 26.62 & 0.12 & 3.16 & 0.75 & 0.07 & 0.24 & 4.02 & 1.91 & 97.58 \\
\hline Mg5 & 47.06 & 13.93 & 0.04 & 27.68 & 0.12 & 1.63 & 0.45 & 0.06 & 0.13 & 5.29 & 0.92 & 97.30 \\
\hline Mg6 & 43.19 & 17.67 & 0.11 & 24.17 & 0.10 & 4.87 & 1.18 & 0.11 & 0.32 & 2.76 & 2.97 & 97.45 \\
\hline Mg7 & 41.27 & 25.25 & 0.08 & 19.92 & 0.10 & 4.67 & 0.79 & 0.05 & 0.27 & 3.03 & 3.01 & 98.43 \\
\hline Mg8 & 46.89 & 18.26 & 0.04 & 22.82 & 0.12 & 2.07 & 0.42 & 0.03 & 0.14 & 7.04 & 1.28 & 99.10 \\
\hline Mg9 & 43.32 & 20.46 & 0.05 & 21.95 & 0.08 & 4.18 & 1.14 & 0.08 & 0.27 & 4.22 & 2.53 & 98.27 \\
\hline Mg10 & 47.35 & 15.99 & 0.04 & 25.60 & 0.12 & 3.48 & 0.86 & 0.06 & 0.28 & 5.74 & 2.30 & 101.83 \\
\hline Ac15 & 50.19 & 14.40 & 0.01 & 22.93 & 0.11 & 1.51 & 0.36 & 0.02 & 0.10 & 8.02 & 1.00 & 98.65 \\
\hline
\end{tabular}




\begin{tabular}{rrrllllllllll} 
Mg11 & 42.30 & 20.99 & 0.05 & 23.01 & 0.12 & 4.36 & 0.90 & 0.09 & 0.40 & 3.35 & 2.61 & 98.18 \\
Mg12 & 45.32 & 16.42 & 0.04 & 27.44 & 0.10 & 2.16 & 0.49 & 0.05 & 0.16 & 4.10 & 1.31 & 97.58 \\
Mg13 & 42.94 & 19.54 & 0.05 & 19.63 & 0.09 & 6.60 & 1.53 & 0.13 & 0.40 & 3.02 & 4.23 & 98.16 \\
Mg14 & 43.45 & 11.18 & 3.02 & 27.87 & 0.11 & 2.54 & 3.61 & 0.08 & 0.15 & 4.16 & 1.47 & 97.65 \\
Mg15 & 46.16 & 11.49 & 0.00 & 31.14 & 0.09 & 1.20 & 0.29 & 0.00 & 0.09 & 5.04 & 0.00 & 95.50 \\
Mg16 & 48.33 & 11.83 & 0.00 & 29.94 & 0.11 & 1.68 & 0.47 & 0.00 & 0.10 & 4.54 & 0.00 & 97.00 \\
Mg17 & 46.73 & 15.18 & 0.04 & 23.41 & 0.10 & 3.31 & 0.58 & 0.06 & 0.20 & 5.72 & 2.02 & 97.35 \\
Mg18 & 50.12 & 10.87 & 0.02 & 22.92 & 0.15 & 11.62 & 0.67 & 0.04 & 0.59 & 3.65 & 2.01 & 102.65 \\
Mg19 & 44.48 & 16.65 & 0.01 & 24.16 & 0.14 & 6.09 & 0.23 & 0.02 & 2.27 & 3.92 & 2.09 & 100.06 \\
Bioclasts & & & & & & & & & & & & \\
B1 & 46.64 & 11.84 & 0.03 & 38.80 & 0.12 & 0.01 & 0.05 & 0.00 & 0.01 & 0.18 & 0.00 & 97.67 \\
B2 & 44.77 & 11.67 & 0.04 & 39.84 & 0.13 & 0.01 & 0.04 & 0.00 & 0.02 & 0.52 & 0.02 & 97.05 \\
B4 & 45.00 & 10.51 & 0.02 & 40.72 & 0.12 & 0.00 & 0.02 & 0.00 & 0.02 & 0.04 & 0.01 & 96.46 \\
B5 & 47.06 & 13.16 & 0.04 & 38.47 & 0.11 & 0.08 & 0.03 & 0.00 & 0.03 & 0.12 & 0.00 & 99.11 \\
\hline
\end{tabular}


Table 5. Major element composition of Niger Fan sediments

\begin{tabular}{|c|c|c|c|c|c|c|c|c|c|c|c|c|c|c|c|c|}
\hline Core & $\begin{array}{c}\text { Depth } \\
(\mathrm{cm})\end{array}$ & $\begin{array}{c}\mathrm{Fe}_{2} \mathrm{O}_{3} \\
\% \\
\end{array}$ & $\begin{array}{c}\mathrm{MnO} \\
\% \\
\end{array}$ & $\begin{array}{c}\mathrm{TiO}_{2} \\
\% \\
\end{array}$ & $\begin{array}{c}\mathrm{CaO} \\
\% \\
\end{array}$ & $\begin{array}{c}\mathrm{K}_{2} \mathrm{O} \\
\% \\
\end{array}$ & $\begin{array}{c}\mathrm{P}_{2} \mathrm{O}_{5} \\
\% \\
\end{array}$ & $\begin{array}{c}\mathrm{SiO}_{2} \\
\% \\
\end{array}$ & $\begin{array}{c}\mathrm{Al}_{2} \mathrm{O}_{3} \\
\% \\
\end{array}$ & $\begin{array}{c}\mathrm{MgO} \\
\% \\
\end{array}$ & $\begin{array}{c}\mathrm{Na}_{2} \mathrm{O} \\
\% \\
\end{array}$ & $\begin{array}{c}\mathrm{SO}_{4} \\
\% \\
\end{array}$ & $\begin{array}{c}\text { LOI } \\
\% \\
\end{array}$ & $\begin{array}{c}\text { Total } \\
\% \\
\end{array}$ & $\begin{array}{c}\mathrm{Ba} \\
\mathrm{ppm}\end{array}$ & $\begin{array}{c}\mathrm{Sr} \\
\mathrm{ppm}\end{array}$ \\
\hline \multicolumn{17}{|c|}{ Mud volcano area } \\
\hline N1-KSF-12 & 105 & 6.93 & 0.06 & 1.06 & 1.57 & 1.28 & 0.13 & 51.34 & 17.84 & 4.32 & 1.25 & $<0.2$ & 13.70 & 99.48 & 276 & $\mathrm{n} / \mathrm{a}$ \\
\hline ' & 200 & 7.95 & 0.03 & 0.74 & 0.54 & 0.97 & 0.08 & 57.30 & 13.67 & 5.26 & 1.23 & 0.26 & 11.68 & 99.71 & 94 & $\mathrm{n} / \mathrm{a}$ \\
\hline ' & 230 & 6.56 & 0.06 & 0.99 & 1.59 & 1.20 & 0.12 & 54.00 & 17.16 & 4.65 & 1.29 & 0.26 & 12.41 & 100.29 & 217 & $\mathrm{n} / \mathrm{a}$ \\
\hline ' & 280 & 10.71 & 0.09 & 0.96 & 0.99 & 1.13 & 0.10 & 48.83 & 16.24 & 4.89 & 1.29 & $<0.2$ & 13.98 & 99.21 & 143 & $\mathrm{n} / \mathrm{a}$ \\
\hline ' & 325 & 7.92 & 0.07 & 0.98 & 1.84 & 1.12 & 0.42 & 50.40 & 17.10 & 4.62 & 1.27 & $<0.2$ & 13.75 & 99.49 & 190 & $\mathrm{n} / \mathrm{a}$ \\
\hline ' & 390 & 7.22 & 0.07 & 1.02 & 1.97 & 1.19 & 0.12 & 50.15 & 17.30 & 4.86 & 1.22 & 0.20 & 14.54 & 99.86 & 147 & $\mathrm{n} / \mathrm{a}$ \\
\hline \multicolumn{17}{|l|}{ Diapir area } \\
\hline $\mathrm{N} 1-\mathrm{KI}-47$ & 3 & 5.15 & 0.38 & 0.72 & 6.05 & 1.61 & 0.13 & 50.65 & 13.95 & 1.58 & 3.45 & 0.37 & 15.70 & 99.74 & 501 & $\mathrm{n} / \mathrm{a}$ \\
\hline ' & 23 & 4.23 & 0.02 & 0.71 & 4.86 & 1.78 & 0.09 & 59.28 & 13.16 & 1.19 & 2.02 & 0.49 & 11.75 & 99.58 & 409 & $\mathrm{n} / \mathrm{a}$ \\
\hline ' & 41 & 6.39 & 0.03 & 0.84 & 2.73 & 1.95 & 0.10 & 56.05 & 16.47 & 1.49 & 2.00 & 0.54 & 11.81 & 100.40 & 445 & $\mathrm{n} / \mathrm{a}$ \\
\hline \multicolumn{17}{|l|}{ Pockmark area } \\
\hline $\mathrm{N} 1-\mathrm{KI}-27$ & 6 & 3.87 & 0.01 & 0.39 & 27.15 & 0.29 & 0.09 & 21.17 & 9.92 & 2.38 & 1.46 & 2.85 & 30.21 & 99.79 & 150 & $\mathrm{n} / \mathrm{a}$ \\
\hline ' & 11 & 4.98 & 0.02 & 0.46 & 22.49 & 0.45 & 0.06 & 24.80 & 11.36 & 1.98 & 2.00 & 3.96 & 26.89 & 99.45 & 95 & $\mathrm{n} / \mathrm{a}$ \\
\hline ' & 18 & 6.76 & 0.03 & 0.64 & 9.96 & 1.49 & 0.08 & 36.37 & 17.09 & 2.25 & 2.75 & 2.68 & 19.62 & 99.72 & 86 & $\mathrm{n} / \mathrm{a}$ \\
\hline N2-KI-20 & 25 & 6.80 & 0.04 & 0.78 & 9.24 & 1.44 & 0.12 & 37.37 & 18.49 & 1.83 & 2.83 & 2.11 & 19.50 & 100.56 & 256 & 434 \\
\hline ' & 70 & 7.57 & 0.05 & 0.80 & 7.52 & 1.55 & 0.11 & 38.86 & 19.34 & 1.59 & 2.77 & 2.48 & 17.99 & 100.64 & 210 & 257 \\
\hline N2-KI-28 & 25 & 7.01 & 0.05 & 0.76 & 9.73 & 1.57 & 0.11 & 38.90 & 17.60 & 1.41 & 2.45 & 3.36 & 17.33 & 100.29 & 291 & 299 \\
\hline ' & 65 & 6.71 & 0.02 & 0.72 & 11.68 & 1.51 & 0.12 & 37.68 & 16.68 & 1.43 & 2.50 & 2.41 & 19.12 & 100.58 & 233 & 346 \\
\hline N2-KI-32 & 5 & 6.91 & 0.05 & 0.81 & 6.57 & 1.54 & 0.14 & 39.54 & 19.00 & 1.84 & 3.69 & 0.44 & 19.42 & 99.95 & 556 & 260 \\
\hline ' & 45 & 7.99 & 0.04 & 0.85 & 2.78 & 1.74 & 0.12 & 44.40 & 21.47 & 1.79 & 2.86 & 0.31 & 15.97 & 100.33 & 465 & 162 \\
\hline N2-KS-44 & 5 & 6.73 & 0.02 & 0.79 & 7.53 & 1.72 & 0.13 & 38.50 & 19.02 & 1.91 & 3.10 & 0.32 & 20.18 & 99.95 & 307 & 376 \\
\hline ' & 60 & 5.64 & 0.05 & 0.55 & 17.60 & 0.95 & 0.09 & 29.35 & 14.44 & 2.31 & 1.82 & 3.30 & 23.98 & 100.07 & 158 & 1356 \\
\hline ' & 130 & 8.27 & 0.07 & 0.85 & 0.35 & 1.98 & 0.09 & 46.74 & 22.62 & 1.82 & 2.71 & 0.42 & 14.24 & 100.16 & 191 & 85 \\
\hline ' & 160 & 3.69 & 0.02 & 0.33 & 28.06 & 0.44 & 0.07 & 20.19 & 9.57 & 3.55 & 1.13 & 3.08 & 30.12 & 100.24 & 57 & 1808 \\
\hline ' & 220 & 7.51 & 0.05 & 0.84 & 5.46 & 1.87 & 0.11 & 42.16 & 19.29 & 2.02 & 2.79 & 0.46 & 16.91 & 99.46 & 206 & 234 \\
\hline ' & 260 & 6.92 & 0.05 & 0.71 & 9.83 & 1.57 & 0.09 & 37.73 & 17.36 & 2.23 & 2.53 & 1.50 & 19.30 & 99.82 & 225 & 500 \\
\hline ' & 330 & 8.80 & 0.08 & 0.75 & 0.75 & 1.95 & 0.09 & 46.28 & 21.53 & 1.99 & 2.79 & 0.48 & 14.61 & 100.11 & 236 & 103 \\
\hline \multicolumn{17}{|c|}{ Reference area } \\
\hline N1-KI-04 & 7 & 6.64 & 5.26 & 0.76 & 6.76 & 1.36 & 0.16 & 36.01 & 15.89 & 2.24 & 4.49 & 0.46 & 19.45 & 99.48 & 820 & $\mathrm{n} / \mathrm{a}$ \\
\hline ' & 35 & 3.60 & 0.04 & 0.46 & 24.45 & 0.38 & 0.09 & 25.34 & 10.82 & 1.36 & 2.31 & 0.49 & 29.48 & 98.82 & 575 & $n / a$ \\
\hline ' & 69 & 7.62 & 0.08 & 0.78 & 3.94 & 1.74 & 0.09 & 43.90 & 19.07 & 2.25 & 3.55 & 0.48 & 16.19 & 99.69 & 582 & $n / a$ \\
\hline
\end{tabular}




\begin{tabular}{|c|c|c|c|c|c|c|c|c|c|c|c|c|c|c|c|}
\hline N2-KI-13 & $\begin{array}{r}5 \\
35 \\
\end{array}$ & $\begin{array}{l}6.86 \\
7.11 \\
\end{array}$ & $\begin{array}{l}0.08 \\
0.09 \\
\end{array}$ & $\begin{array}{l}0.80 \\
0.78 \\
\end{array}$ & $\begin{array}{l}7.06 \\
5.58 \\
\end{array}$ & $\begin{array}{l}1.54 \\
1.57 \\
\end{array}$ & $\begin{array}{l}0.14 \\
0.13 \\
\end{array}$ & $\begin{array}{l}40.92 \\
42.63 \\
\end{array}$ & $\begin{array}{l}18.26 \\
18.83 \\
\end{array}$ & $\begin{array}{l}1.84 \\
1.79 \\
\end{array}$ & $\begin{array}{l}3.44 \\
3.32 \\
\end{array}$ & $\begin{array}{l}0.41 \\
0.57 \\
\end{array}$ & $\begin{array}{l}19.14 \\
17.92 \\
\end{array}$ & $\begin{array}{l}100.48 \\
100.31 \\
\end{array}$ & $\begin{array}{l}615 \\
627 \\
\end{array}$ \\
\hline
\end{tabular}

n/a: not analyzed 
Table 6. Sr/Ca and Mg/Ca ratios of end-member components

\begin{tabular}{lcc}
\hline End-member & $\mathrm{Sr} / \mathrm{Ca}$ & $\mathrm{Mg} / \mathrm{Ca}$ \\
\hline Aragonite & 0.027 & 0.0005 \\
High-Mg calcite & 0.003 & 0.17 \\
Biogenic calcite & 0.0028 & 0.0006 \\
Detrital fraction & 0.035 & 3.7 \\
\hline
\end{tabular}

References: Aragonite - This study, Naehr et al. (2000);

High-Mg calcite - This study; Biogenic calcite - Rosenthal et al. (1997)

Stoll and Schrag (1999), Rickaby et al. (2002), Lear et al. (2002,2003)

Detrital fraction: This study 


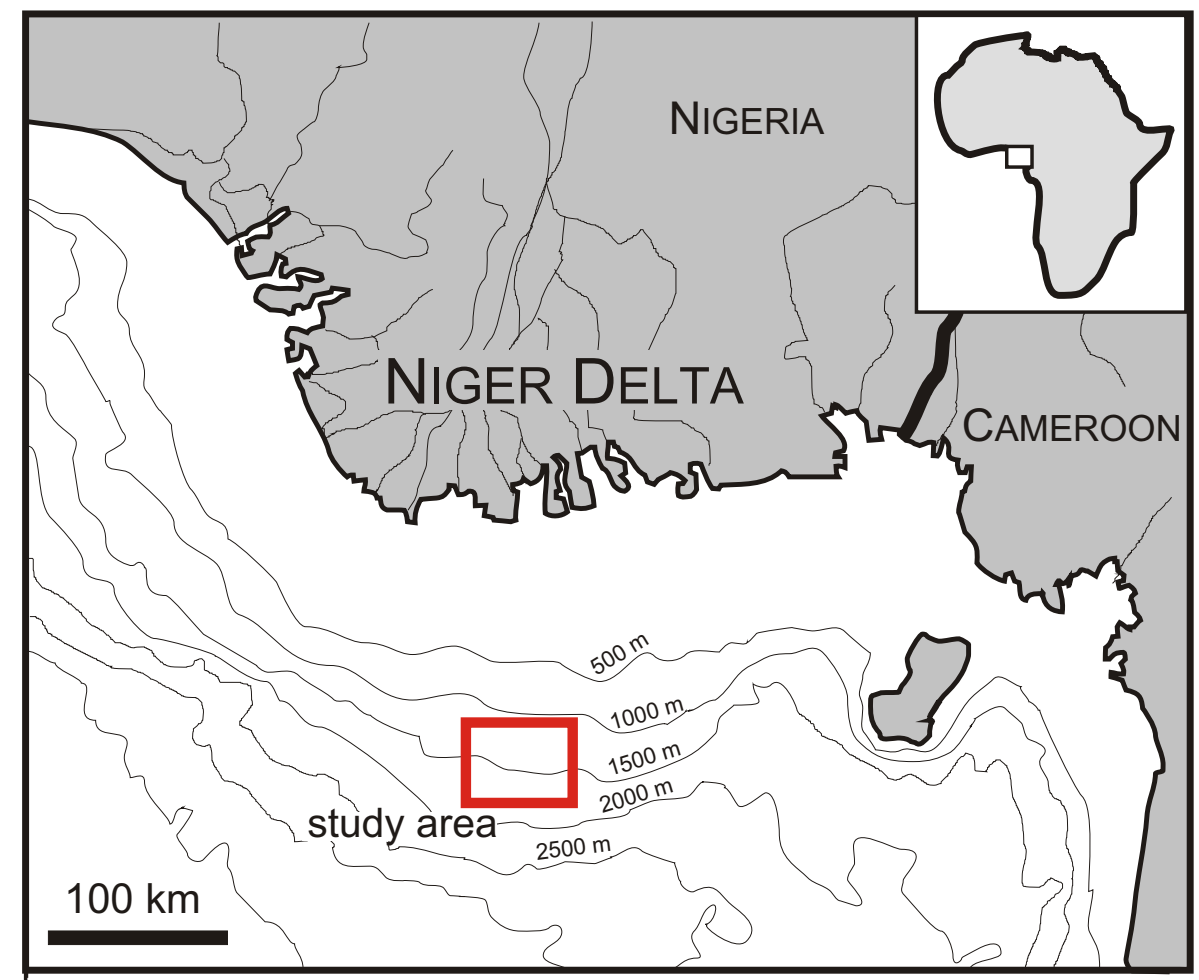

Fig. 1. Location of the study area on the Niger Delta deep province 


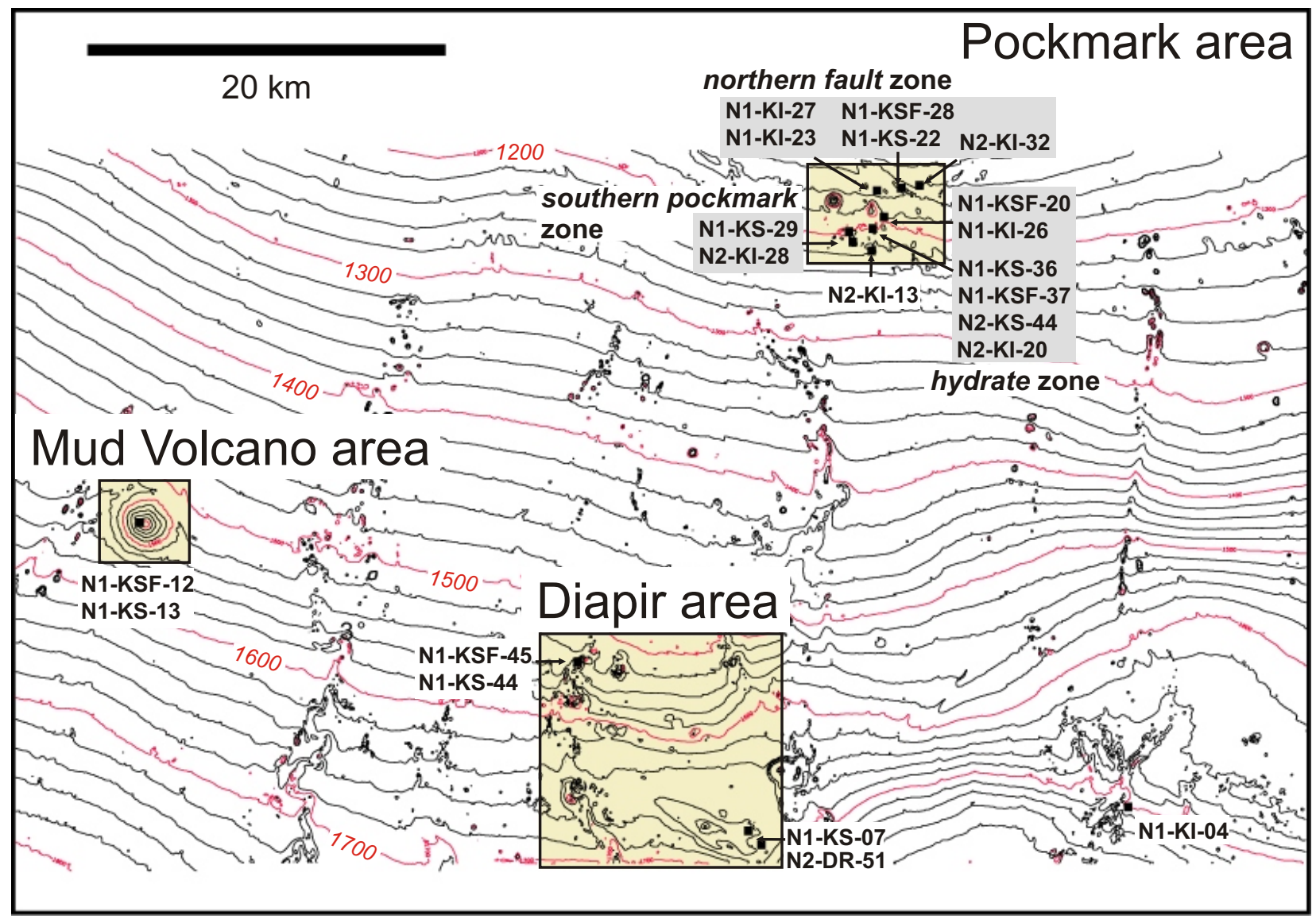

Fig. 2. Study area on the Niger Delta deep province with positions of the cores discussed in the text 
Siderite nodules

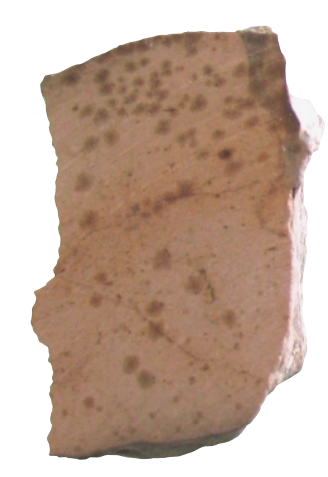

N1-KSF-13 (1 m)
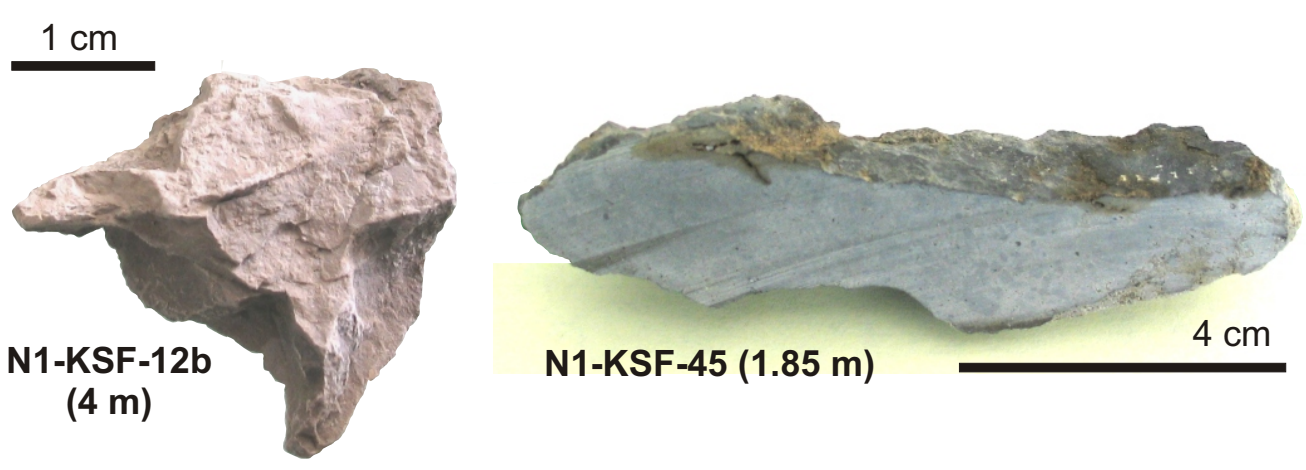

\section{Chemoherm carbonates}

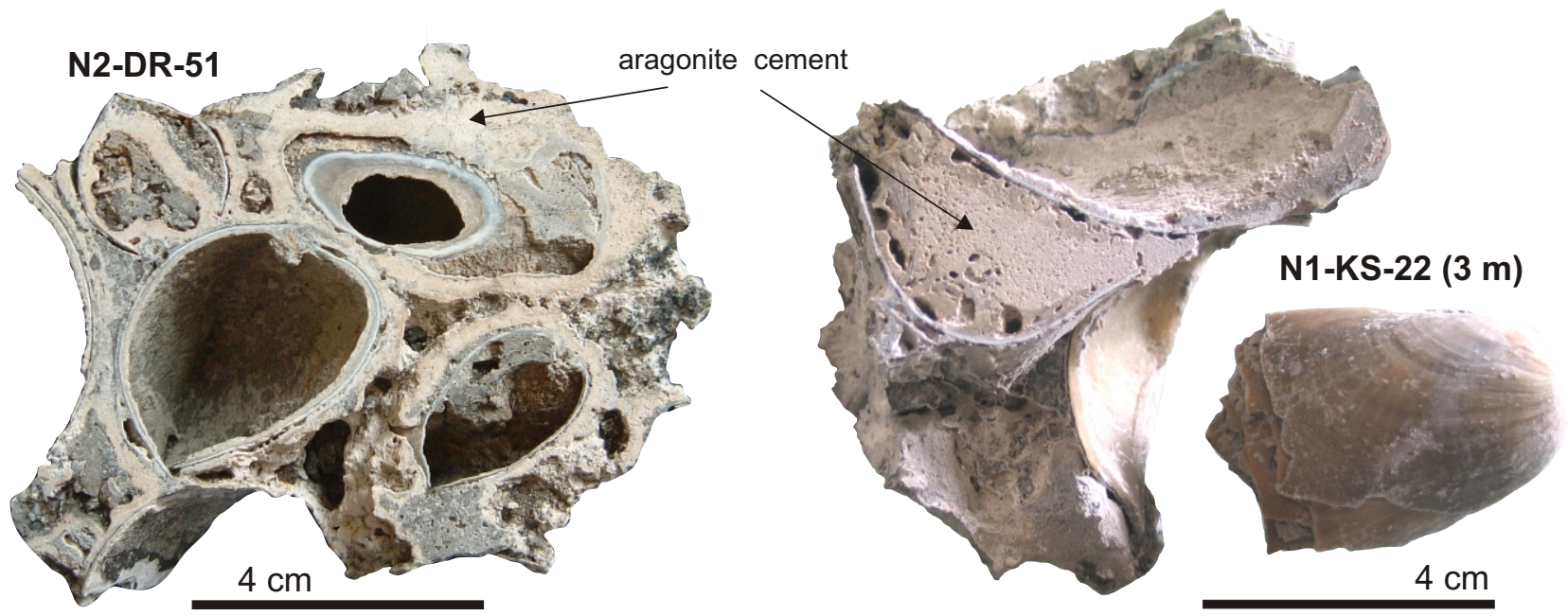

Carbonate-cemented breccias

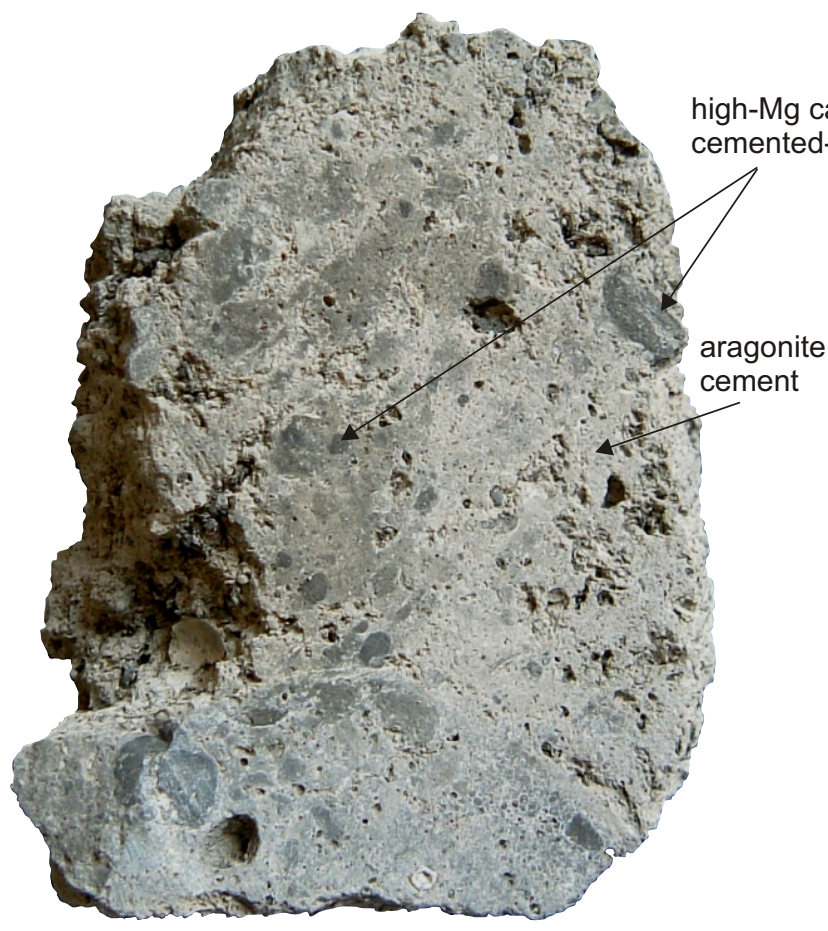

N1-KS-36 (2.1 m)

$2 \mathrm{~cm}$

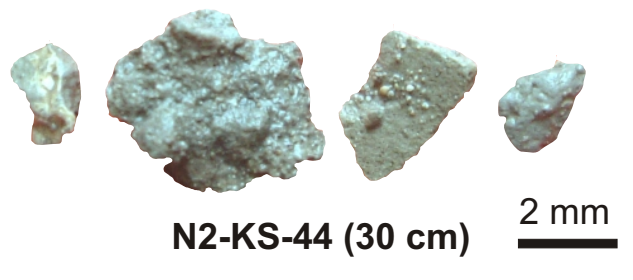

Gas hydrate carbonate

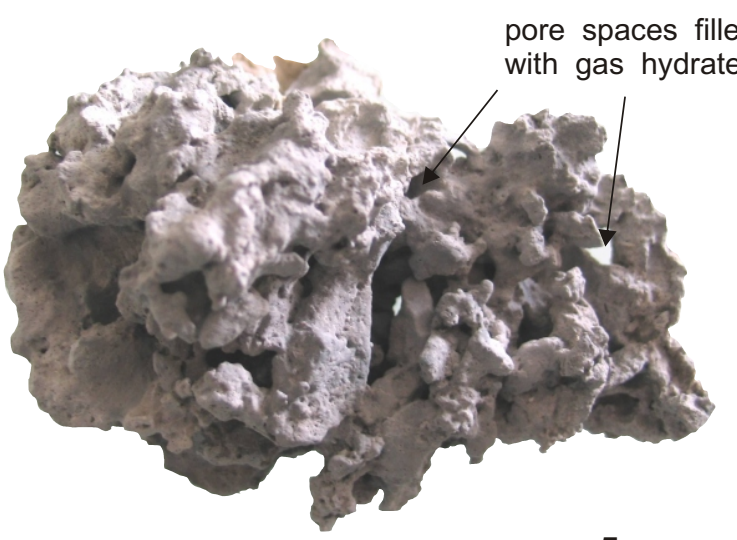

$\mathrm{N} 1-\mathrm{KI}-26(65 \mathrm{~cm})$

Fig. 3. Photographs of authigenic carbonates from the Niger Fan. Nodules of siderite (Mud Volcano); dolomite nodule (Diapir area); chemoherm carbonates (Diapir area and northern fault zone, Pockmark area); carbonate-cemented breccias and gas hydrate carbonate (hydrate zone). 

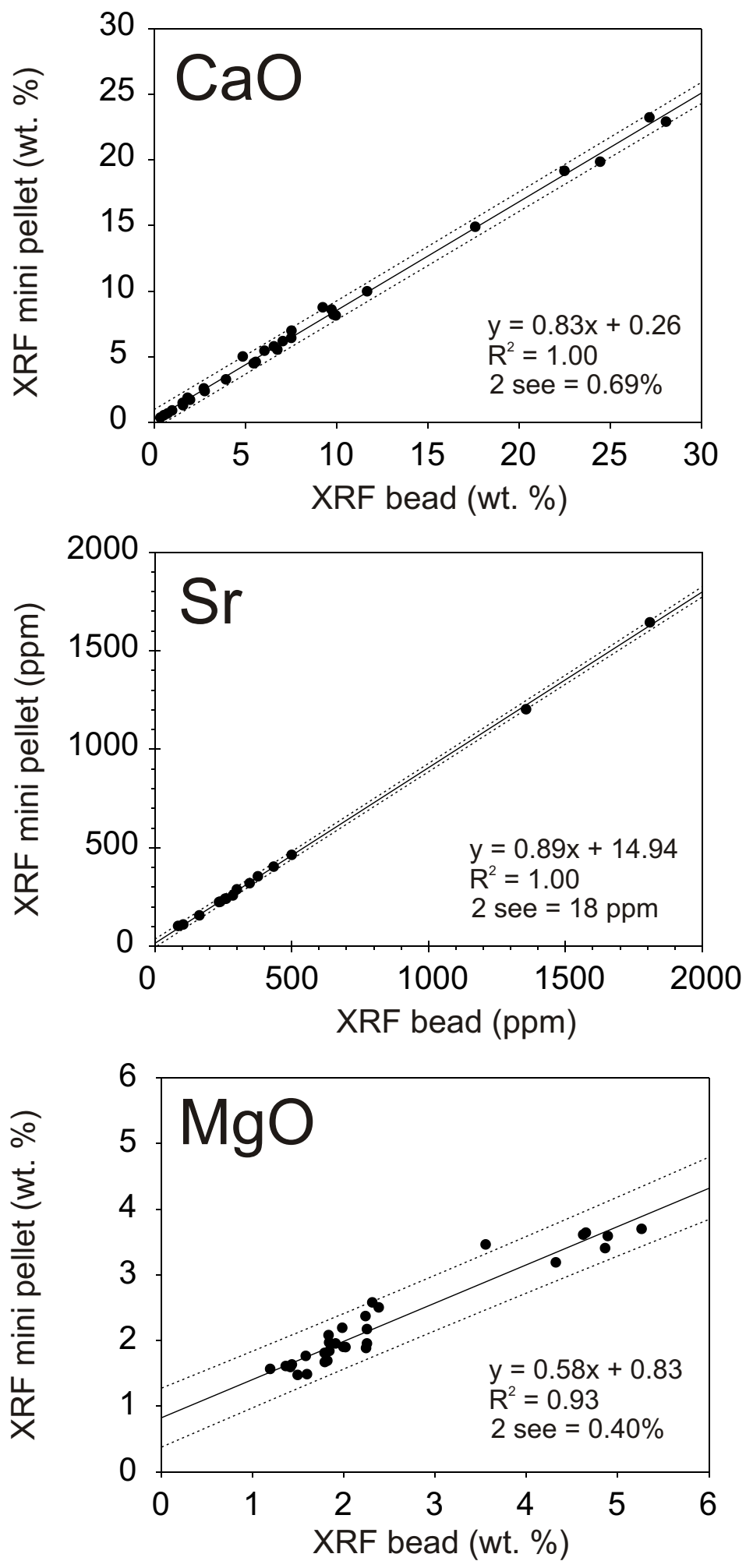

Fig. 4. Mini pellet (200 mg) XRF data versus conventional (bead) XRF data for Niger Fan sediments. Least squares regression lines are shown with the $95 \%$ prediction intervals. The standard error of the estimate ( 2 see) is a measure of the accuracy of predictions made with regression lines. 
A) Interface cores (Reference and Diapir areas)

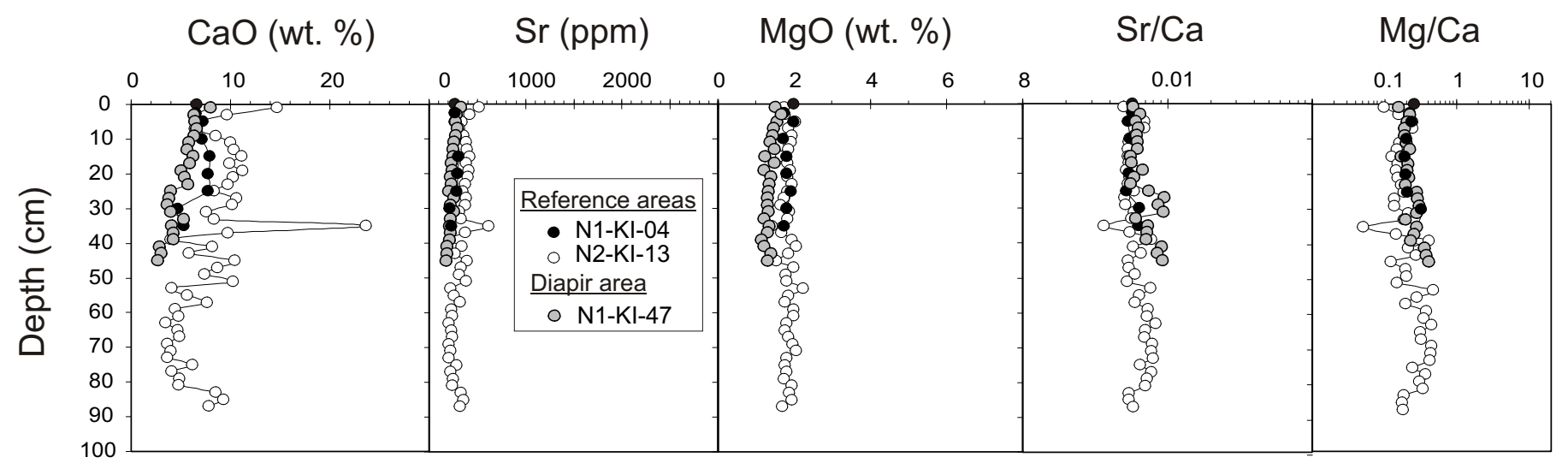

B) Interface cores (Pockmark area)

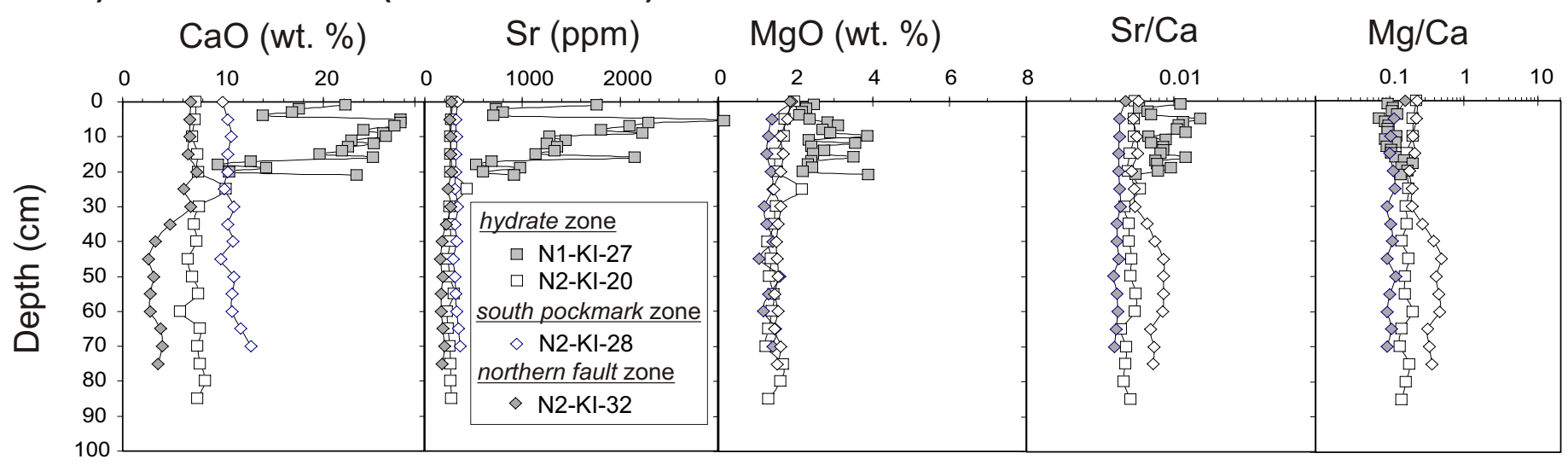

\section{C) Kullenberg cores}

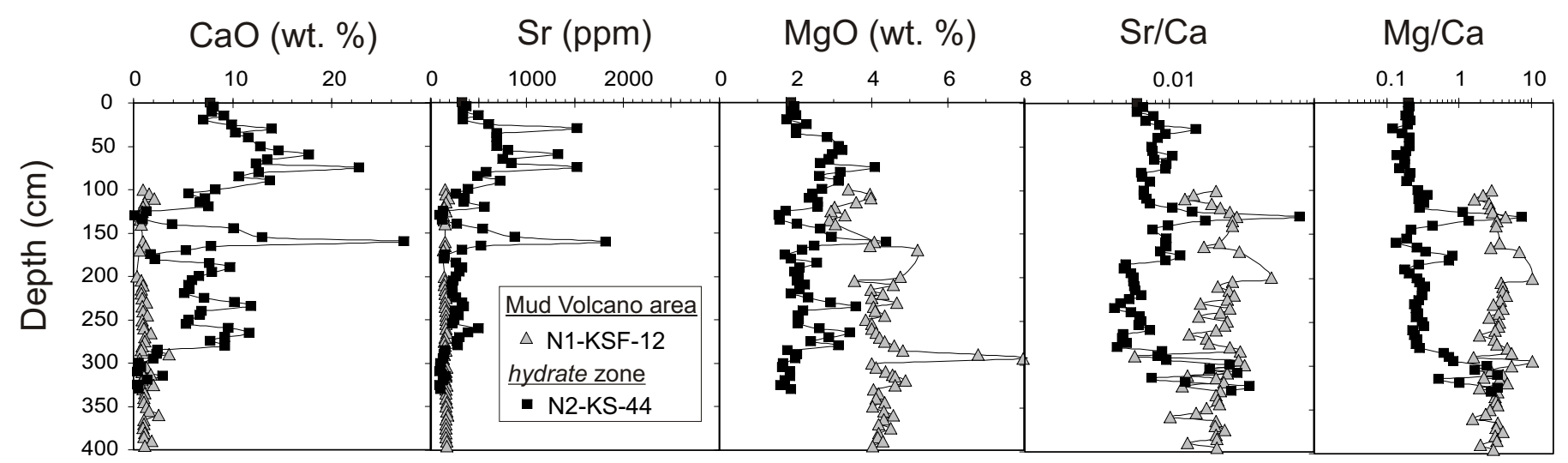

Fig. 5. Downcore profiles of $\mathrm{CaO}(w t \%), \mathrm{Sr}(\mathrm{ppm}), \mathrm{MgO}(\mathrm{wt} \%), \mathrm{Sr} / \mathrm{Ca}$ and $\mathrm{Mg} / \mathrm{Ca}$ (wt ratios) for A) Interface cores from the Reference (N1-KI-04, N2-KI-13) and Diapir (N1-KI-47) areas; B) Interface cores from the Pockmark area (N2-KI-20, N2-KI-28, N2-KI-32, N1-KI-27) and C) Kullenberg cores (N1-KSF-12, N2-KS-44). 


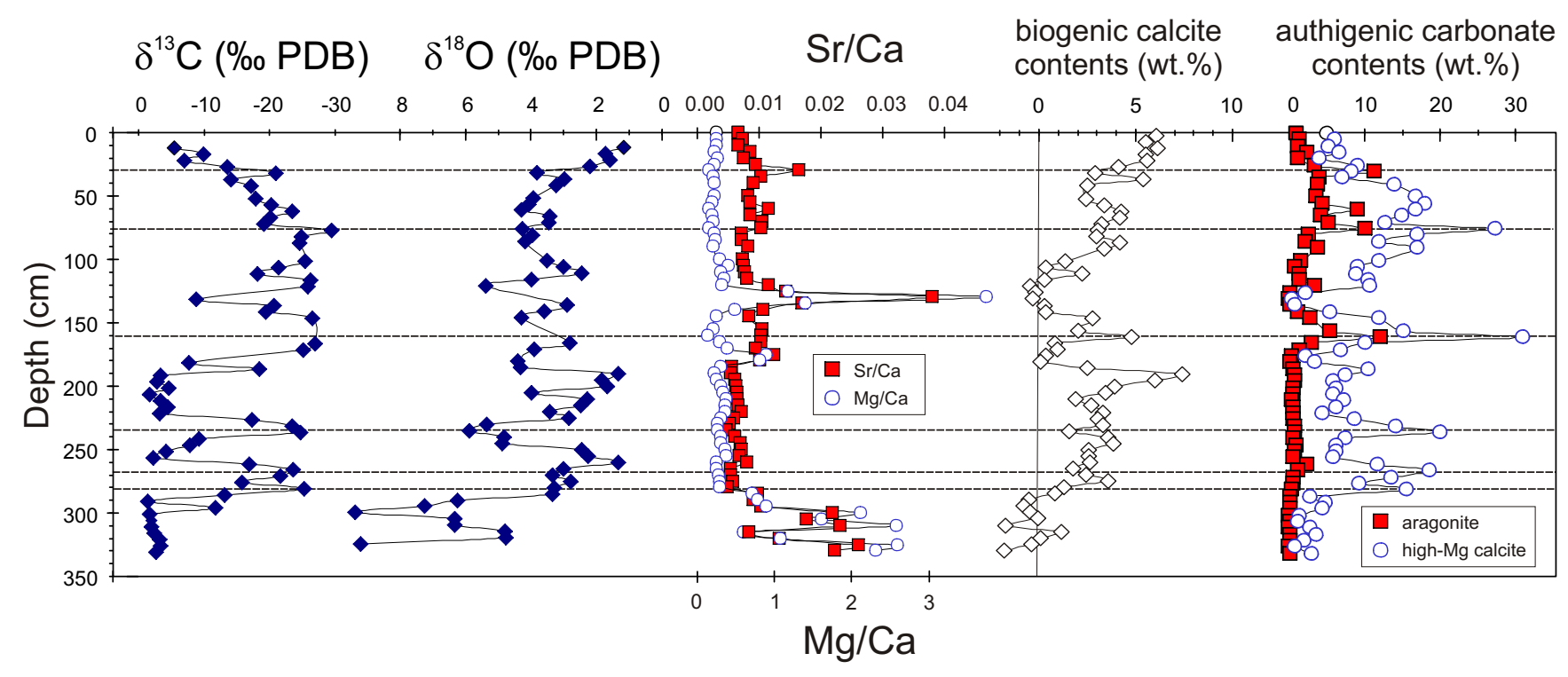

Fig. 6. Down-core profiles of stable isotope ratios, $\mathrm{Sr} / \mathrm{Ca}$ and $\mathrm{Mg} / \mathrm{Ca}$ (wt ratio), and modelled aragonite, high-Mg calcite and biogenic calcite contents (wt \%) for core N2-KS-44 (Hydrate zone, Pockmark area). The $\delta^{13} \mathrm{C}$ negative excursions match perfectly with modelled contents for aragonite and high-Mg calcite (see dashed lines). The high $\mathrm{Sr} / \mathrm{Ca}$ and $\mathrm{Mg} / \mathrm{Ca}$ ratios at $130 \mathrm{~cm}$ and below $300 \mathrm{~cm}$ correspond to layers of carbonate-poor detrital sediments. 


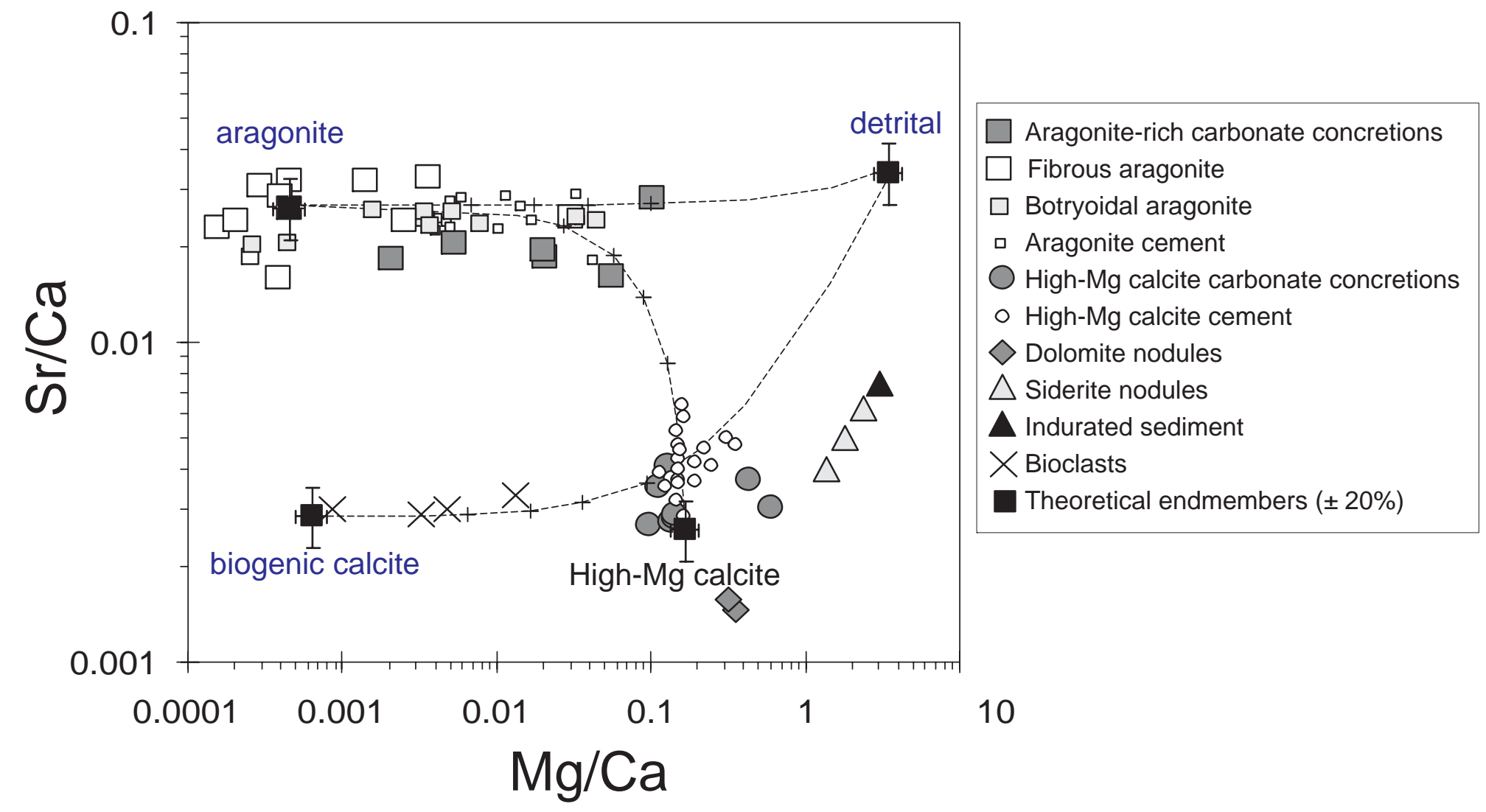

Fig. 7. Relationship between $\mathrm{Sr} / \mathrm{Ca}$ and $\mathrm{Mg} / \mathrm{Ca}$ (wt ratio) in cold seep carbonate concretions and authigenic minerals. The dashed lines correspond to mixing lines between hypothetical endmembers (aragonite, high-Mg calcite, biogenic calcite, detrital). 

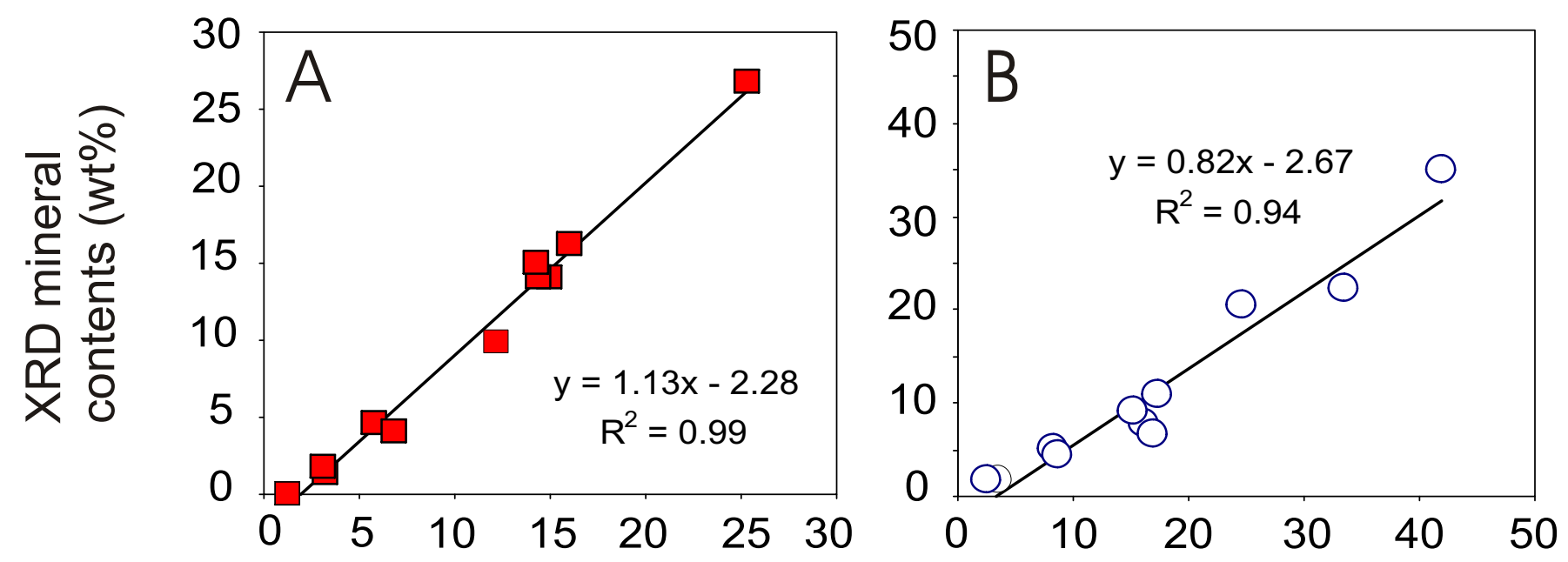

Modelled mineral contents ( $w t \%)$

Fig. 8. Direct quantitative XRD data versus modelled mineral contents (using $\mathrm{Sr} / \mathrm{Ca}$ and $\mathrm{Mg} / \mathrm{Ca}$ ratios) for aragonite and high- $\mathrm{Mg}$ calcite in Niger Fan sediments (core N2-KS-44). 
A

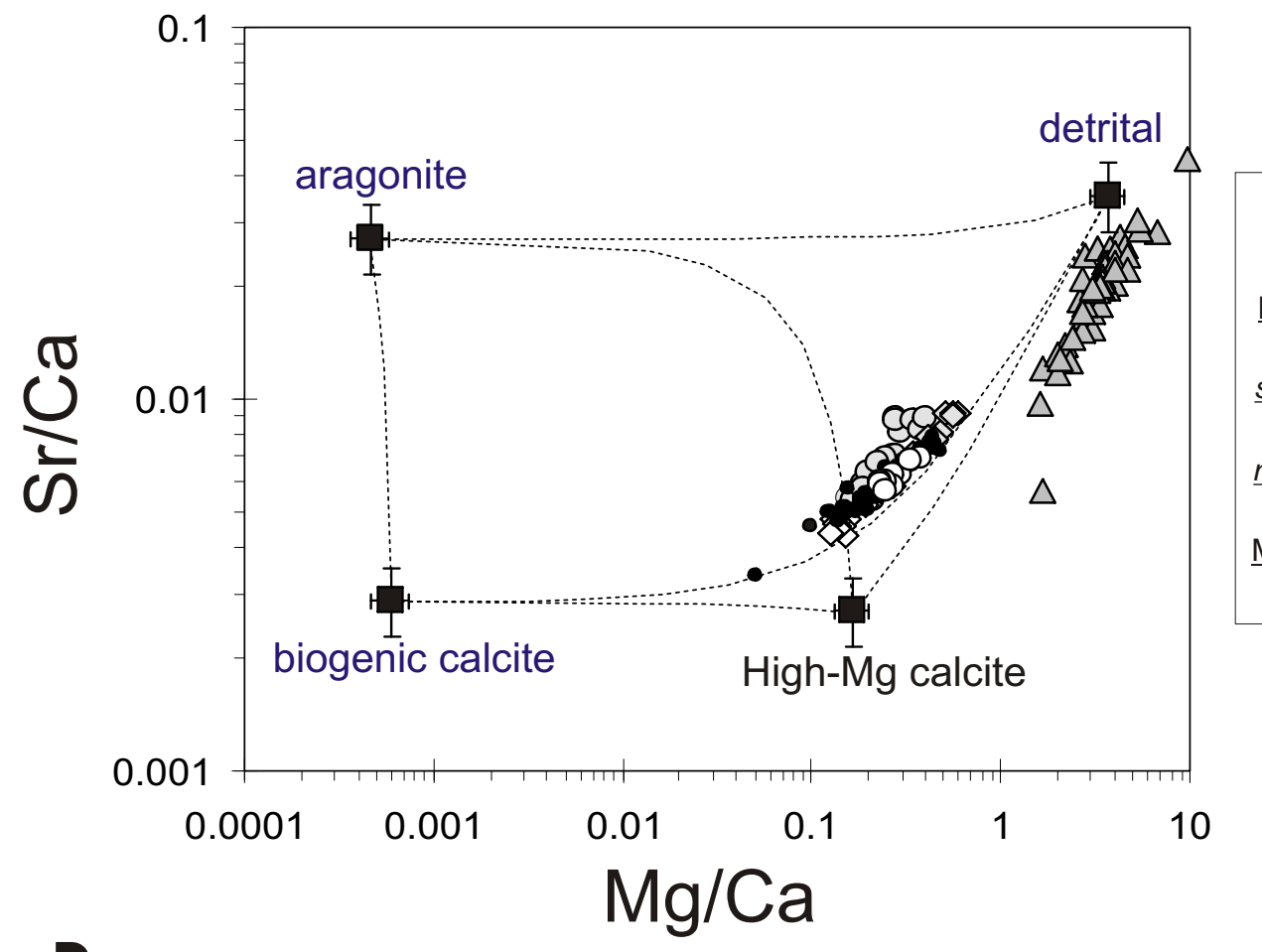

Reference areas

- $\mathrm{N} 1-\mathrm{KI}-04$

O N2-Kl-13

Diapir area

O N1-KI-47

southern pockmark zone

$\diamond \mathrm{N} 2-\mathrm{KI}-28$

northern fault zone

$\diamond \mathrm{N} 2-\mathrm{KI}-32$

Mud Volcano area

$\triangle \mathrm{N} 1-\mathrm{KSF}-12$

B

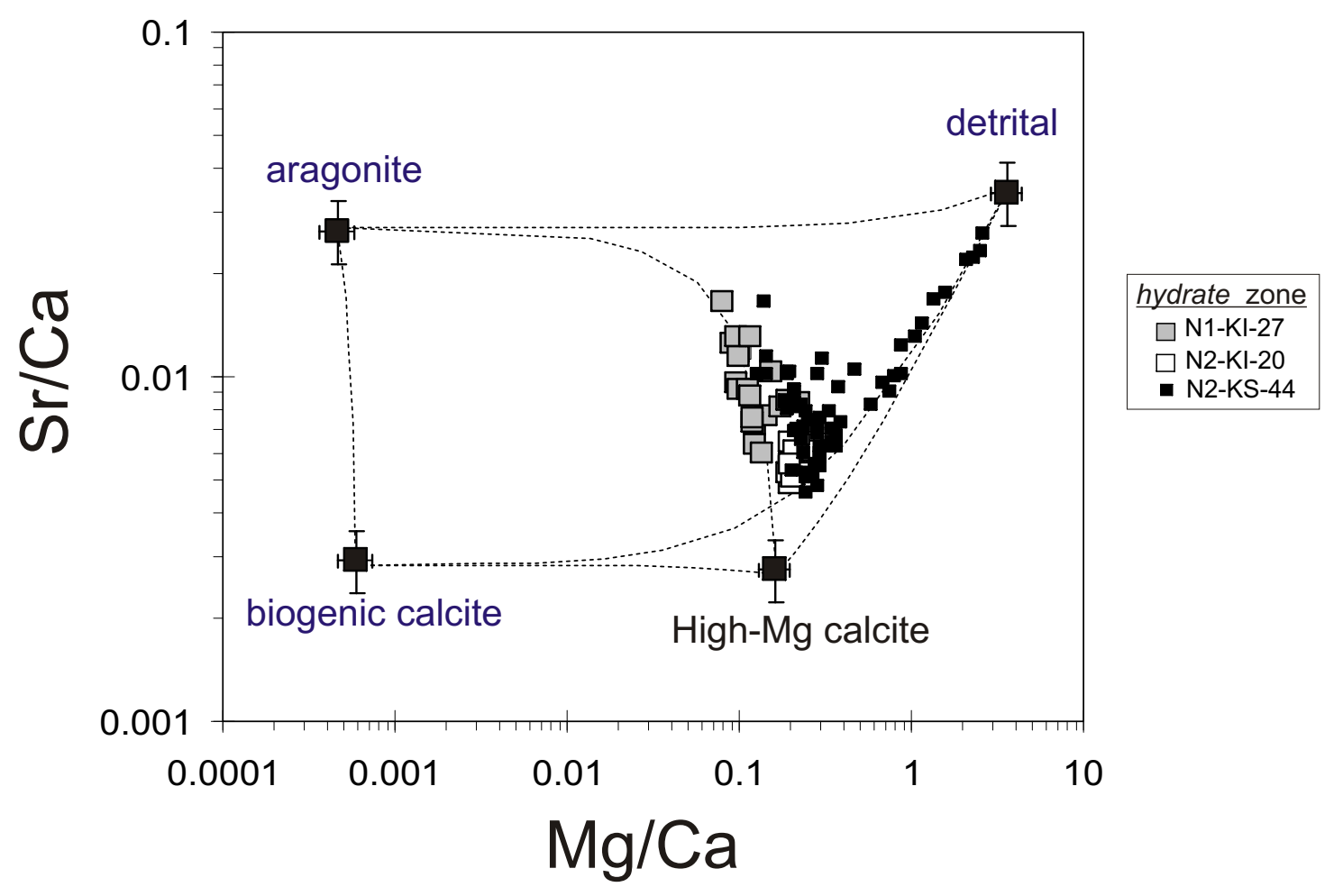

Fig. 9. Relationship between $\mathrm{Sr} / \mathrm{Ca}$ and $\mathrm{Mg} / \mathrm{Ca}$ (wt ratio) in Niger Delta sediments. A. Sediments from reference, Diapir, Mud Volcano, and Pockmark (southern pockmark and northern fault zones) areas. B. Sediments from the hydrate zone (Pockmark area). The dashed lines correspond to mixing lines between hypothetical endmembers (aragonite, high-Mg calcite, biogenic calcite, detrital). 